\title{
Systematic Overview of Aristolochic Acids: Nephrotoxicity, Carcinogenicity, and Underlying Mechanisms
}

\author{
Jiayin Hant, Zhong Xiant, Yushi Zhang, Jing Liu and Aihua Liang* \\ Key Laboratory of Beijing for Identification and Safety Evaluation of Chinese Medicine, Institute of Chinese Materia Medica, \\ China Academy of Chinese Medical Sciences, Beijing, China
}

Aristolochic acids (AAs) are a group of toxins commonly present in the plants of genus Aristolochia and Asarum, which are spread all over the world. Since the 1990s, AA-induced nephropathy (AAN) and upper tract urothelial carcinoma (UTUC) have been reported in many countries. The underlying mechanisms of AAN and AA-induced UTUC have been extensively investigated. AA-derived DNA adducts are recognized as specific biomarkers of

\section{OPEN ACCESS}

Edited by:

Eleonore Fröhlich,

Medical University of Graz, Austria

Reviewed by:

Francis Johnson,

Stony Brook University,

United States

Viktoriya Sidorenko,

Stony Brook University,

United States

*Correspondence:

Aihua Liang

ahliang@icmm.ac.cn

tThese authors have contributed equally to this work.

Specialty section: This article was submitted to

Predictive Toxicology,

a section of the journal

Frontiers in Pharmacology

Received: 31 January 2019 Accepted: 20 May 2019

Published: 11 June 2019

Citation:

Han J, Xian Z, Zhang Y, Liu J and Liang A (2019) Systematic Overview of Aristolochic Acids: Nephrotoxicity,

Carcinogenicity, and Underlying Mechanisms.

Front. Pharmacol. 10:648. doi: 10.3389/ fphar.2019.00648
AA exposure, and a mutational signature predominantly characterized by $A \rightarrow T$ transversions has been detected in AA-induced UTUC tumor tissues. In addition, various enzymes and organic anion transporters are involved in AA-induced adverse reactions. The progressive lesions and mutational events initiated by AAs are irreversible, and no effective therapeutic regimen for AAN and AA-induced UTUC has been established until now. Because of several warnings on the toxic effects of AAs by the US Food and Drug Administration and the regulatory authorities of some other countries, the sale and use of AA-containing products have been banned or restricted in most countries. However, AA-related adverse events still occur, especially in the Asian and Balkan regions. Therefore, the use of AA-containing herbal remedies and the consumption of food contaminated by AAs still carry high risk. More strict precautions should be taken to protect the public from AA exposure.

Keywords: aristolochic acids, aristolochic acid nephropathy, Balkan endemic nephropathy, upper tract urothelial carcinoma, mechanisms of nephrotoxicity, carcinogenicity of aristolochic acids

\section{INTRODUCTION}

Aristolochic acids (AAs) are identified as a group of toxins that can cause end-stage renal failure associated with urothelial carcinoma. In 1992, a high prevalence of kidney disease accompanied by urothelial carcinoma in female patients ingesting slimming pills raised worldwide attention to the high nephrotoxic and carcinogenic potential of AAs. Subsequently, Balkan endemic nephropathy (BEN) has also been found to be associated with the exposure to AAs. Since then, different studies have addressed the characterization and quantitation of AA analogs in plants and products, and the underlying mechanisms involved in the adverse reactions of AAs have been broadly described (Zhou et al., 2019).

\section{ARISTOLOCHIC ACIDS}

AAs are abundant in the plants of genus Aristolochia and Asarum, which are spread all over the world (Hashimoto et al., 1999; Wooltorton, 2004; Liang et al., 2017). So far, more than 178 AA analogs 
have been isolated from natural sources (Michl et al., 2014), in which at least seven species of Aristolochia, including Aristolochia indica L. (Asia), A. serpentaria L. (North America), A. debilis Sieb and Zucch. (China), A. acuminata Lam (India), A. trilobata L. (Central/South America, Caribbean), A. clematitis L. (Europe), and A. bracteolata Lam. (Africa) (Heinrich et al., 2009), as well as four species of Asarum, including Asarum heteropoides f. mandshuricum (Maxim). Kitag and A. sieboldii Miq (China), A. europaeum L. (Europe), and A. canadense L (Canada and USA) (Michl et al., 2017) are used medicinally. Herbs or products containing AAs are commonly used for treating cold, headache, aphthous stomatitis, inflammatory diseases, snake bites, and sexual problems (Li et al., 2010; Kuo et al., 2012; Michl et al., 2013; Bhattacharjee et al., 2017; Liang et al., 2017). Since nephrotoxicity and carcinogenicity of AAs have been recognized, the US Food and Drug Administration and regulatory authorities of some other countries have issued alerts against the use and import of products containing parts of Aristolochia. The sale and use of AA-containing products are banned or restricted in most countries. However, in the US and Europe, herbal supplements containing AAs could be easily purchased through the Internet (Gold and Slone, 2003; Schaneberg and Khan, 2004; Michl et al., 2013). In addition, in China and some Asian countries, herbal remedies and products containing herb preparations from Aristolochia and Asarum are still used, and millions of people may be at risk of developing AA-related disease (Hu et al., 2004; Grollman, 2013; Rosenquist and Grollman, 2016). Studies have been performed to assess the AA content in different plants and products. Some typical AA analogs (Figure 1) obtained from plants and Chinese patent medicines are listed in Tables $\mathbf{1}$ and 2.

\section{ARISTOLOCHIC ACID-INDUCED ADVERSE REACTIONS}

\section{Aristolochic Acid Nephropathy}

AA nephropathy (AAN) is a kind of chronic tubulointerstitial renal disease accompanied by upper tract urothelial carcinoma (UTUC) in almost half of the cases (Nortier et al., 2000). In 1992, some female patients from Belgium who consumed slimming pills containing Chinese herbs suffered from rapidly progressive interstitial nephritis (Vanherweghem et al., 1993). The renal failure was characterized by extensive interstitial fibrosis with atrophy, loss of tubules, and hyperplasia of the urothelium mainly localized in the superficial cortex (Cosyns et al., 1994a; Depierreux et al., 1994). Thereafter, urothelial carcinoma occurred in more than $40 \%$ of the patients consuming these Chinese herbs (Cosyns et al., 1994b; Nortier et al., 2000; Lord et al., 2001; Nortier and Vanherweghem, 2002). After investigations, it was found that Stephania tetranda was inadvertently substituted by Aristolochia fangchi, which contained nephrotoxic constituents (AAs) leading to adverse events (Vanhaelen et al., 1994). AAs were substantiated as the chief culprit because AA-derived DNA adducts were detected in the kidneys and ureteric tissues of these patients (Schmeiser et al., 1996; Nortier et al., 2000; Lord et al., 2001). Since then, AAN has raised worldwide attention (Jadot et al., 2017). Long-term ingestion of herbal formula known or<smiles>[R]c1cc2c(cc([N+](=O)[O-])c3c(C(=O)O)cc4c(c32)OCO4)c([R9])c1[R2]</smiles>

aristolochic acid I (AAl, $\mathrm{C}_{17} \mathrm{H}_{11} \mathrm{NO}_{7}$ ): $\mathrm{R}_{1}=\mathrm{H}, \mathrm{R}_{2}=\mathrm{H}, \mathrm{R}_{3}=\mathrm{OCH}_{3}$ aristolochic acid II (AAll, $\mathrm{C}_{16} \mathrm{H}_{9} \mathrm{NO}_{6}$ ): $\mathrm{R}_{1}=\mathrm{H}, \mathrm{R}_{2}=\mathrm{H}, \mathrm{R}_{3}=\mathrm{H}$ aristolochic acid Illa (AAlla, $\mathrm{C}_{16} \mathrm{H}_{9} \mathrm{NO}_{7}$ ): $\mathrm{R}_{1}=\mathrm{OH}, \mathrm{R}_{2}=\mathrm{H}, \mathrm{R}_{3}=\mathrm{H}$ aristolochic acid IV (AAIV, $\mathrm{C}_{18} \mathrm{H}_{13} \mathrm{NO}_{8}$ ): $\mathrm{R}_{1}=\mathrm{OCH}_{3}, \mathrm{R}_{2}=\mathrm{H}, \mathrm{R}_{3}=\mathrm{OCH}_{3}$ aristolochic acid IVa (AAIVa, $\mathrm{C}_{17} \mathrm{H}_{11} \mathrm{NO}_{8}$ ): $\mathrm{R}_{1}=\mathrm{OH}, \mathrm{R}_{2}=\mathrm{H}, \mathrm{R}_{3}=\mathrm{OCH}_{3}$ aristolochic acid VIla (AAVIla, $\mathrm{C}_{17} \mathrm{H}_{11} \mathrm{NO}_{8}$ ): $\mathrm{R}_{1}=\mathrm{H}, \mathrm{R}_{2}=\mathrm{OH}, \mathrm{R}_{3}=\mathrm{OCH}_{3}$ 7-hydroxy-aristolochic acid I (7-OH-AAI, $\mathrm{C}_{17} \mathrm{H}_{11} \mathrm{NO}_{8}$ ): $\mathrm{R}_{1}=\mathrm{H}, \mathrm{R}_{2}=\mathrm{OH}, \mathrm{R}_{3}=\mathrm{OCH}_{3}$<smiles>[R]c1cc([R6])c2cc3c4c(cc5c(c4c2c1)OCO5)C(=O)N3</smiles>

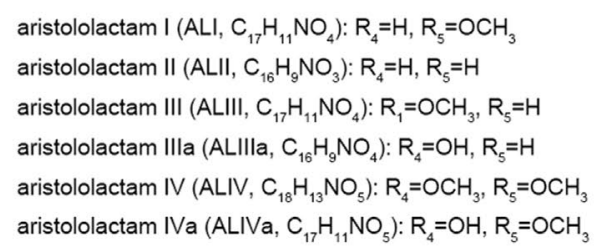<smiles>COc1c(O)cc2c3c(cc4ccccc4c13)NC2=O</smiles>

aristololactam All (ALAll, $\mathrm{C}_{16} \mathrm{H}_{11} \mathrm{NO}_{3}$ )

FIGURE 1 | Chemical structures of some typical AA analogs.

suspected to contain AAs is one of the prominent risk factors for developing AAN (Jia et al., 2005; Vervaet et al., 2017). Although the sale and use of AA-containing products are banned or restricted in most of the countries (Krell and Stebbing, 2013), 


\begin{tabular}{|c|c|c|c|c|c|c|c|c|c|c|c|c|c|c|c|}
\hline Botanical name & Plant part & AAI & AAII & $\begin{array}{l}\text { AA } \\
\text { IIIa }\end{array}$ & AAIV & $\begin{array}{l}\text { AA } \\
\text { IVa }\end{array}$ & $\begin{array}{l}\text { AA } \\
\text { VIla }\end{array}$ & 7-OH-AAI & ALI & ALII & ALIII & ALIIIa & ALIV & ALIVa & AL All \\
\hline Aristolochia albida (Michl et al., 2016) & Root & 1.346 & 1.413 & 0.402 & NR & 0.055 & NR & NR & 0.007 & NR & NR & NR & NR & NR & NR \\
\hline Aristolochia argentina (Michl et al., 2016) & Stem & 0.085 & 0.156 & - & NR & 0.003 & NR & NR & - & NR & NR & NR & NR & NR & NR \\
\hline Aristolochia austroszechuanica (Zhou et al., 2008) & Root or root tuber & 1.050 & NR & NR & NR & NR & NR & NR & NR & NR & NR & NR & NR & NR & NR \\
\hline Aristolochia baetica (Michl et al., 2016) & Leaf & 0.086 & 0.073 & 0.002 & NR & 0.001 & NR & NR & - & NR & NR & NR & NR & NR & NR \\
\hline Aristolochia californica (Michl et al., 2016) & Stem & 0.802 & 0.070 & 0.002 & NR & 0.008 & $\mathrm{NR}$ & NR & 0.013 & NR & NR & $\mathrm{NR}$ & NR & $\mathrm{NR}$ & $\mathrm{NR}$ \\
\hline Aristolochia chamissonis (Michl et al., 2016) & Leaf & 0.682 & - & - & NR & 0.004 & NR & NR & 0.003 & NR & NR & NR & NR & NR & NR \\
\hline $\begin{array}{l}\text { Aristolochia cinnabarina (Zhou et al., 2008; } \\
\text { Zhang et al., 2013b; Wang and Chan, 2014; } \\
\text { Yu et al., 2016; Li et al., 2017) }\end{array}$ & Root & $\begin{array}{l}0.887- \\
12.098\end{array}$ & $\begin{array}{c}0.659- \\
5.076\end{array}$ & 0.841 & NR & 0.246 & NR & NR & - & + & NR & + & NR & NR & - \\
\hline Aristolochia clematitis (Michl et al., 2016) & Root & 1.496 & 2.557 & 0.048 & NR & 0.014 & NR & NR & 0.002 & NR & NR & NR & NR & NR & NR \\
\hline $\begin{array}{l}\text { Aristolochia contorta (Zhai et al., 2006; Yuan et } \\
\text { al., 2007a; Yuan et al., 2007b; Yuan et al., 2008; } \\
\text { Xu et al., 2010; Liu et al., 2011; Xu et al., 2013; } \\
\text { Li et al., 2017; Mao et al., 2017; Ding et al., 2018) }\end{array}$ & Fruit & $\begin{array}{c}0.034- \\
4.695\end{array}$ & $\begin{array}{c}0.010- \\
0.574\end{array}$ & $\begin{array}{l}0.006- \\
2.081\end{array}$ & NR & $\begin{array}{c}0.019- \\
1.370\end{array}$ & $\begin{array}{c}0.019- \\
0.610\end{array}$ & $\begin{array}{c}0.765- \\
0.902\end{array}$ & $\begin{array}{c}0.071- \\
0.446\end{array}$ & $\begin{array}{c}0.012- \\
0.061\end{array}$ & $<L O Q$ & 0.021 & $<L O Q$ & $\begin{array}{c}0.045- \\
1.080\end{array}$ & $\begin{array}{c}0.010- \\
0.048\end{array}$ \\
\hline Aristolochia contorta (Mao et al., 2017) & Seed & $\begin{array}{c}0.840- \\
2.293\end{array}$ & $\begin{array}{c}0.014- \\
0.132\end{array}$ & NR & NR & NR & NR & NR & NR & NR & NR & NR & NR & NR & NR \\
\hline $\begin{array}{l}\text { Aristolochia contorta (Mohamed et al., 1999; Wei } \\
\text { et al., 2005; Zhai et al., 2006; Zhang et al., 2006; } \\
\text { Kuo et al., 2010) }\end{array}$ & Root & $\begin{array}{l}0.511- \\
6.421\end{array}$ & $\begin{array}{c}0.029- \\
6.108\end{array}$ & 0.462 & NR & $\begin{array}{c}0.375- \\
0.688\end{array}$ & NR & NR & $\begin{array}{c}0.017- \\
0.020\end{array}$ & $\begin{array}{c}0.015- \\
0.021\end{array}$ & NR & NR & NR & NR & NR \\
\hline $\begin{array}{l}\text { Aristolochia contorta (Zhai et al., 2006; Yuan et al., } \\
\text { 2007a; Yuan et al., 2008) }\end{array}$ & Herb & $\begin{array}{l}0.127- \\
10.460\end{array}$ & $\begin{array}{c}0.034- \\
6.325\end{array}$ & $\begin{array}{c}0.375- \\
1.085\end{array}$ & NR & $\begin{array}{c}0.258- \\
0.308\end{array}$ & NR & $\begin{array}{c}1.030- \\
1.150\end{array}$ & 0.021 & - & NR & $\begin{array}{c}0.026- \\
0.105\end{array}$ & NR & 0.010 & 0.015 \\
\hline Aristolochia cucurbitifolia (Michl et al., 2016) & Leaf & 1.107 & 0.122 & 0.004 & NR & 0.009 & NR & NR & 0.122 & NR & NR & NR & NR & NR & NR \\
\hline Aristolochia cymbifera (Michl et al., 2016) & Stem & 0.016 & 0.127 & 0.005 & NR & 0.004 & NR & NR & - & NR & NR & NR & NR & NR & NR \\
\hline $\begin{array}{l}\text { Aristolochia debilis (Hashimoto et al., 1998; Liu et al., } \\
\text { 2005; Xu et al., 2013; Li et al., 2017) }\end{array}$ & Fruit & $\begin{array}{c}0.299- \\
1.532\end{array}$ & $\begin{array}{c}0.064- \\
0.524\end{array}$ & $\begin{array}{c}0.369- \\
1.179\end{array}$ & NR & $\begin{array}{c}0.030- \\
0.240\end{array}$ & $\begin{array}{c}0.318- \\
0.872\end{array}$ & NR & $\begin{array}{c}0.027- \\
0.462\end{array}$ & $\begin{array}{c}0.017- \\
0.046\end{array}$ & NR & NR & NR & NR & NR \\
\hline Aristolochia debilis (Michl et al., 2016) & Stem & $\begin{array}{c}0.012- \\
0.035\end{array}$ & - & 0.211 & NR & $\begin{array}{l}0.024- \\
0.111\end{array}$ & NR & NR & $\begin{array}{c}0.004- \\
0.006\end{array}$ & NR & NR & NR & NR & NR & NR \\
\hline $\begin{array}{l}\text { Aristolochia debilis (Mohamed et al., 1999; Liu et al., } \\
\text { 2005; Yuan et al., 2007a; Yuan et al., 2007b; } \\
\text { Kuo et al., 2010; Kong et al., 2015; Li et al., 2017; } \\
\text { Ding et al., 2018) }\end{array}$ & Root & $\begin{array}{c}0.078- \\
2.610\end{array}$ & $\begin{array}{c}0.013- \\
0.875\end{array}$ & $\begin{array}{c}0.004- \\
1.400\end{array}$ & $\begin{array}{c}0.120- \\
0.180\end{array}$ & $\begin{array}{c}0.002- \\
1.750\end{array}$ & NR & $\begin{array}{c}0.284- \\
0.615\end{array}$ & $\begin{array}{c}0.007- \\
0.023\end{array}$ & $\begin{array}{c}0.004- \\
0.271\end{array}$ & $\begin{array}{c}0.011- \\
0.016\end{array}$ & $<L O D$ & 0.096 & 0.096 & $\begin{array}{c}0.102- \\
0.285\end{array}$ \\
\hline Aristolochia debilis (Yuan et al., 2007b) & Herb & 0.175 & 0.039 & 0.481 & NR & 0.245 & NR & 1.290 & NR & $<\mathrm{LOQ}$ & 0.016 & NR & $<\mathrm{LOQ}$ & NR & NR \\
\hline Aritolochia elegans (Jou et al., 2004) & NR & + & + & N & + & + & NR & NR & N & NR & NR & NR & NR & NR & + \\
\hline Aristolochia fangchi (Kuo et al., 2010) & Fruit & 0.945 & 0.050 & NR & NR & NR & NR & NR & NR & NR & NR & NR & NR & NR & NR \\
\hline Aristolochia fimbriata (Michl et al., 2016) & Stem & 0.180 & - & - & NR & 0.006 & NR & NR & 0.016 & NR & NR & NR & NR & NR & NR \\
\hline Aristolochia fontanesii (Michl et al., 2016) & Leaf & 0.855 & 0.102 & 0.106 & NR & 0.092 & NR & NR & 0.002 & NR & NR & NR & NR & NR & NR \\
\hline Aritolochia foveolata (Jou et al., 2004) & $N R$ & + & + & + & + & + & NR & NR & + & NR & NR & NR & NR & NR & $N$ \\
\hline Aristolochia gibertii (Michl et al., 2016) & Leaf & 0.050 & 1.875 & 0.003 & NR & - & NR & NR & - & NR & NR & NR & NR & NR & NR \\
\hline Aristolochia grandiffora (Michl et al., 2016) & Root & 0.066 & - & 0.148 & NR & 0.049 & NR & NR & 0.028 & NR & NR & NR & NR & NR & NR \\
\hline Aristolochia guentheri (Michl et al., 2016) & Stem & $\begin{array}{c}0.002- \\
0.005\end{array}$ & - & - & NR & 0.017 & NR & NR & 0.057 & NR & NR & NR & NR & NR & NR \\
\hline $\begin{array}{l}\text { Aristolochia heterophylla (Mohamed et al., 1999; } \\
\text { Jou et al., 2003; Zhou et al., 2008) }\end{array}$ & Stems and roots & $\begin{array}{l}1.640- \\
3.260\end{array}$ & + & + & NR & + & NR & NR & NR & NR & NR & NR & NR & NR & NR \\
\hline Aristolochia heterophylla (Zhou et al., 2008) & Root or root tuber & $\begin{array}{l}1.320- \\
4.450\end{array}$ & NR & NR & NR & NR & NR & NR & NR & NR & NR & NR & NR & NR & NR \\
\hline Aristolochia indica (Michl et al., 2016) & Root & 0.818 & 0.239 & 0.117 & NR & 0.029 & NR & NR & 0.018 & NR & NR & NR & NR & NR & NR \\
\hline Aristolochia kaempferi (Michl et al., 2016) & Stem & 1.202 & 1.261 & 0.017 & NR & 0.023 & NR & NR & - & NR & NR & NR & NR & NR & NR \\
\hline
\end{tabular}

Aristolochia cucurbitifolia (Michl et al., 2016)

Aristolochia cymbifera (Michl et al., 2016)

Aristolochia debilis (Hashimoto et al., 1998; Liu et al.

2005; Xu et al., 2013; Li et al., 2017)

Aristolochia debilis (Mohamed et al., 1999; Liu et al.,

2005; Yuan et al., 2007a; Yuan et al., 2007b;

Ding et al., 2018)

Aristolochia debilis (Yuan et al., 2007b)

Aritolochia elegans (Jou et al., 2004)

Aristolochia fangchi (Kuo et al., 2010)

Aristolochia heterophylla (Mohamed et al., 1999;

Aristolochia kaempferi (Michl ot al. 2016 )

Stem

$\begin{array}{ll}1.261 & 0.017\end{array}$ 


\begin{tabular}{|c|c|c|c|c|c|c|c|c|c|c|c|c|c|c|c|}
\hline Botanical name & Plant part & AAI & AAll & $\begin{array}{l}\text { AA } \\
\text { IIla }\end{array}$ & AAIV & $\begin{array}{l}\text { AA } \\
\text { IVa }\end{array}$ & $\begin{array}{l}\text { AA } \\
\text { VIla }\end{array}$ & 7-OH-AAI & ALI & ALII & ALIII & ALIIIa & ALIV & ALIVa & AL All \\
\hline Aristolochia labiate (Michl et al., 2016) & Leaf & 0.003 & - & - & $\mathrm{NR}$ & - & NR & NR & - & NR & NR & NR & NR & NR & NR \\
\hline Aristolochia lagesinan (Michl et al., 2016) & Stem & 0.008 & - & - & NR & - & NR & NR & 0.034 & NR & NR & NR & NR & NR & NR \\
\hline Aristolochia littoralis (Michl et al., 2016) & Root & 0.070 & 0.048 & 0.260 & NR & 0.097 & NR & $N R$ & 0.034 & NR & NR & NR & NR & NR & NR \\
\hline Aristolochia liukiensis (Michl et al., 2016) & Stem & 0.708 & 0.176 & 0.167 & NR & 0.094 & NR & NR & 0.001 & NR & NR & NR & NR & NR & NR \\
\hline Aristolochia macrophylla (Michl et al., 2016) & Stem & 0.014 & 0.000 & 0.009 & NR & 0.008 & NR & NR & - & NR & NR & NR & NR & NR & NR \\
\hline Aristolochia maurorum (Michl et al., 2016) & Leaf & 0.140 & - & 0.002 & NR & 0.006 & NR & NR & 0.003 & NR & NR & NR & NR & NR & NR \\
\hline $\begin{array}{l}\text { Aristolochia manshuirensis (Hashimoto et al., 1998; } \\
\text { Liu et al., 2005; Zhai et al., 2006; Yuan et al., 2007a; } \\
\text { Yuan et al., 2007b; Han et al., 2008; Yuan et al., } \\
\text { 2008; Kong et al., 2015; Yu et al., 2016; Li et al., } \\
\text { 2017) }\end{array}$ & Stem & $\begin{array}{l}0.310- \\
10.850\end{array}$ & $\begin{array}{c}0.130- \\
2.977\end{array}$ & $\begin{array}{c}0.050- \\
0.652\end{array}$ & $\begin{array}{c}0.350- \\
1.230\end{array}$ & $\begin{array}{c}0.090- \\
0.497\end{array}$ & NR & $<L O D$ & $\begin{array}{c}0.000- \\
0.002\end{array}$ & $\begin{array}{c}0.002- \\
0.006\end{array}$ & $\begin{array}{c}0.000- \\
0.002\end{array}$ & 0.098 & $<\mathrm{LOD}$ & $<L O D$ & $<\mathrm{LOD}$ \\
\hline Aristolochia manshuirensis (Michl et al., 2016) & Leaf & $\begin{array}{c}0.938- \\
1.019\end{array}$ & $\begin{array}{c}1.317- \\
1.673\end{array}$ & $\begin{array}{c}0.002- \\
0.009\end{array}$ & NR & $\begin{array}{c}0.000- \\
0.009\end{array}$ & NR & NR & $\begin{array}{c}0.001- \\
0.004\end{array}$ & NR & NR & NR & NR & NR & NR \\
\hline Aristolochia maxima (Michl et al., 2016) & Root & $\begin{array}{c}2.151- \\
2.467\end{array}$ & $\begin{array}{c}0.540- \\
1.438\end{array}$ & $\begin{array}{c}0.022- \\
0.024\end{array}$ & NR & $\begin{array}{c}0.017- \\
0.020\end{array}$ & NR & NR & $\begin{array}{c}0.001- \\
0.004\end{array}$ & NR & NR & NR & NR & NR & NR \\
\hline $\begin{array}{l}\text { Aristolochia mollissima (Liu et al., 2003; Yuan et al., } \\
\text { 2007a; Yuan et al., 2007b; Han et al., 2008; } \\
\text { Yuan et al., 2008; Yu et al., 2016) }\end{array}$ & Herb & $\begin{array}{c}0.106- \\
2.650\end{array}$ & $\begin{array}{c}0.022- \\
0.038\end{array}$ & $\begin{array}{c}0.025- \\
0.158\end{array}$ & NR & $\begin{array}{c}0.041- \\
0.058\end{array}$ & NR & $\begin{array}{c}0.092- \\
0.108\end{array}$ & - & $<L O D$ & $<\mathrm{LOD}$ & $<\mathrm{LOQ}$ & $<\mathrm{LOD}$ & 0.010 & $<\mathrm{LOQ}$ \\
\hline Aristolochia mollissima (Zhou et al., 2008) & Aerial part & 0.050 & NR & NR & NR & NR & NR & NR & NR & NR & NR & NR & NR & NR & NR \\
\hline Aristolochia mollissima (Mohamed et al., 1999) & Stem and root & 0.465 & NR & NR & NR & NR & $N R$ & $N R$ & NR & NR & NR & NR & NR & NR & NR \\
\hline Aristolochia mollissima (Michl et al., 2016) & Leaf & 1.234 & - & 0.001 & NR & 0.006 & NR & $N R$ & 0.001 & $N R$ & NR & NR & NR & NR & NR \\
\hline Aristolochia moupinensis (Michl et al., 2016) & Leaf & 1.164 & 0.140 & 0.005 & NR & 0.038 & NR & NR & 0.002 & NR & NR & NR & NR & NR & NR \\
\hline Aristolochia moupinensis (Zhou et al., 2008) & Root or root tuber & $\begin{array}{c}0.540- \\
2.780\end{array}$ & NR & NR & NR & NR & NR & NR & NR & NR & NR & NR & NR & NR & NR \\
\hline Aristolochia moupinensis (Zhou et al., 2008) & Stem & $\begin{array}{c}0.540- \\
2.150\end{array}$ & NR & NR & NR & NR & NR & $N R$ & NR & NR & NR & NR & NR & NR & NR \\
\hline Aristolochia odoratissima (Michl et al., 2016) & Leaf & 0.054 & - & - & NR & 0.003 & NR & $N R$ & - & NR & NR & NR & NR & NR & NR \\
\hline Aristolochia ovalifolia (Michl et al., 2016) & Leaf & 0.419 & - & - & NR & 0.001 & NR & $N R$ & 0.013 & NR & NR & NR & NR & NR & NR \\
\hline Aristolochia paucinervis (Michl et al., 2016) & Fruit & 1.597 & 0.931 & 0.034 & NR & 0.055 & $N R$ & $N R$ & 0.054 & $N R$ & NR & NR & NR & NR & NR \\
\hline Aristolochia pothieri (Michl et al., 2016) & Leaf & - & - & - & NR & - & NR & NR & 0.114 & NR & NR & NR & NR & NR & NR \\
\hline Aristolochia ringens (Michl et al., 2016) & Root & 0.668 & 0.138 & - & NR & 0.026 & $N R$ & NR & 0.002 & NR & NR & NR & NR & NR & NR \\
\hline Aristolochia rotunda (Michl et al., 2016) & Root & 1.629 & 1.518 & 0.159 & NR & 0.052 & NR & NR & 0.005 & NR & NR & NR & NR & NR & NR \\
\hline Aristolochia sempervirens (Michl et al., 2016) & Leaf & 0.676 & 0.073 & 0.007 & NR & 0.028 & NR & NR & 0.005 & NR & NR & NR & NR & NR & NR \\
\hline Aristolochia serpentaria (Michl et al., 2016) & Fruit & 0.992 & 0.077 & 0.002 & NR & 0.013 & NR & $N R$ & 0.017 & NR & NR & NR & NR & NR & NR \\
\hline Aritolochia shimadi (Jou et al., 2004) & NR & + & + & + & + & + & NR & $N R$ & N & NR & NR & NR & NR & NR & $N$ \\
\hline Aristolochia tagala (Michl et al., 2016) & Root & 1.347 & 0.090 & 0.243 & NR & 0.121 & NR & $N R$ & 0.006 & NR & NR & NR & NR & NR & NR \\
\hline Aristolochia taliscana (Michl et al., 2016) & Stem & 0.010 & - & - & NR & - & NR & $N R$ & - & NR & NR & NR & NR & NR & NR \\
\hline Aristolochia tomentosa (Michl et al., 2016) & Stem & 1.047 & 0.370 & 0.029 & NR & 0.023 & NR & NR & 0.001 & NR & NR & NR & NR & NR & NR \\
\hline Aristolochia triangularis (Michl et al., 2016) & Stem & 0.025 & - & 0.001 & NR & 0.032 & NR & NR & 0.005 & NR & NR & NR & NR & NR & NR \\
\hline Aristolochia trilobata (Michl et al., 2016) & Stem & 0.435 & 0.157 & 0.109 & NR & 0.017 & NR & $N R$ & 0.012 & NR & NR & NR & NR & NR & NR \\
\hline Aristolochia westlandii (Michl et al., 2016) & Stem & 0.001 & - & - & NR & - & NR & NR & - & NR & NR & NR & NR & NR & NR \\
\hline Aristolochia zollingeriana (Michl et al., 2016) & Leaf & $\begin{array}{c}0.945- \\
1.189\end{array}$ & $\begin{array}{c}1.745- \\
2.289\end{array}$ & $\begin{array}{c}0.033- \\
0.052\end{array}$ & NR & $\begin{array}{c}0.008- \\
0.010\end{array}$ & NR & NR & $\begin{array}{c}0.004- \\
0.011\end{array}$ & NR & NR & NR & NR & NR & NR \\
\hline Asarum caudigelellum (Han et al., 2008) & NR & $\begin{array}{c}0.150- \\
0.220\end{array}$ & NR & NR & NR & NR & NR & NR & NR & NR & NR & NR & NR & NR & NR \\
\hline $\begin{array}{l}\text { Asarum heterotropides (Yuan et al., 2007a; Yuan } \\
\text { et al., 2007b; Yuan et al., 2008; Zhou et al., 2008) }\end{array}$ & Herb & $\begin{array}{c}0.040- \\
0.110\end{array}$ & 0.025 & $\begin{array}{l}0.055- \\
0.060\end{array}$ & $\begin{array}{c}0.054- \\
0.058\end{array}$ & 0.047 & NR & 0.041 & 0.048 & 0.005 & $<\mathrm{LOD}$ & $\begin{array}{l}0.009- \\
0.031\end{array}$ & $<L O D$ & $<\mathrm{LOD}$ & $<\mathrm{LOQ}$ \\
\hline
\end{tabular}




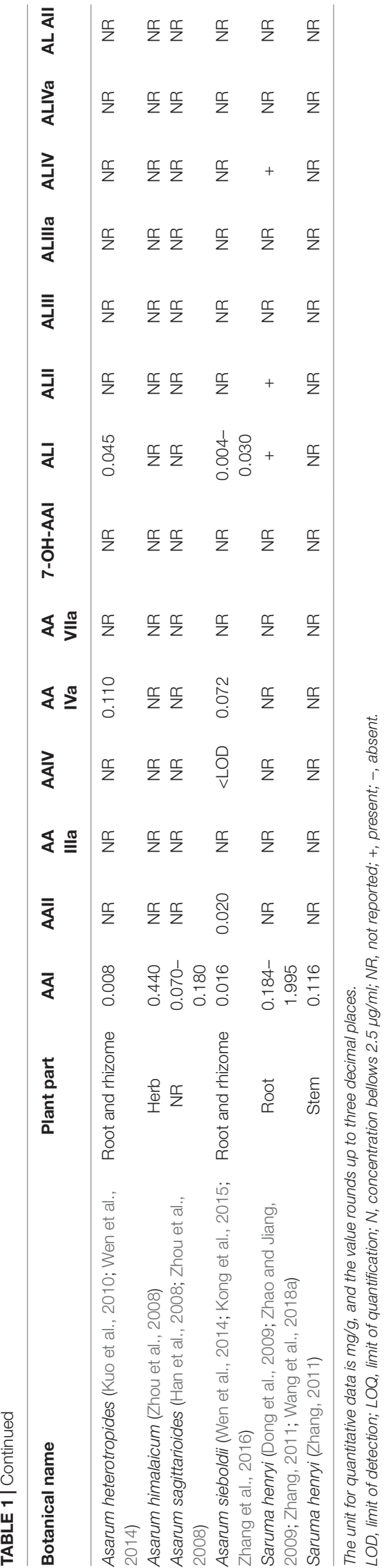

AAN induced by numerous herbal remedies and products are still reported from all over the world (Lord et al., 1999; Yang et al., 2006; Debelle et al., 2008; Shaohua et al., 2010; Wu et al., 2012; Vaclavik et al., 2014; Ban et al., 2018).

Generally, most AAN patients display an unusually rapid progression towards end-stage renal disease. During clinical examination, mildhypertension, severeanemia, increased serum creatinine, decreased estimated glomerular filtration rate, proteinuria, glycosuria, and/or leukocyturia may be observed in most cases (Reginster et al., 1997; Meyer et al., 2000; Yang et al., 2012; Gokmen et al., 2013). More precisely, some studies reveal that microalbuminuria and proteinuria of tubular type can serve as early screening indicators of AAN (Kabanda et al., 1995; Trnacevic et al., 2017). Estimation of neutral endopeptidase, a 94-kDa ectoenzyme of the proximal tubule brush border, which is characteristically decreased in AAN patients, may also serve as an early clinical biomarker of AAN (Nortier et al., 1997). During renal tract ultrasonic inspection, shrunken kidneys are observed, which results in asymmetrical and irregular cortical outline (Gokmen et al., 2013). Microscopically, the typical findings are extensive interstitial fibrosis with atrophy and loss of tubules localized predominantly in the superficial cortex and progressing towards the inner cortex. The interstitium is remarkably hypocellular in a majority of the cases. Interstitial inflammatory infiltration is observed in some cases, and more inflammatory cells are found as compared with other renal diseases. The glomeruli are relatively spared. The collapse of the capillaries and wrinkling of the basement membrane are noticed in a few glomeruli. Glomerular lesions mainly include ischemic, microcystic, obsolescent glomeruli, occasional thrombotic microangiopathy-like lesions, and/or focal segmental sclerosislike lesions. Multifocal thickening of interlobular and afferent arterioles and/or splitting up of peritubular capillary basement membranes may be observed, which are associated with arteriolar hyalinosis, intimal fibrous hyperplasia, and occasional mucoid arterial intimal fibrosis (Depierreux et al., 1994; Meyer et al., 2000; Stefanovic et al., 2007; Debelle et al., 2008; Jelakovic et al., 2014; Jadot et al., 2017).

\section{Balkan Endemic Nephropathy}

After AAs were substantiated as one of the main causative agents inducing rapidly progressive renal disease, some scientists proposed that the clinical and morphological features of different stages of AAN and the patterns of the famous BEN were strikingly similar. This provided a clue that BEN may also be related to AAs (Cosyns et al., 1994a; Arlt et al., 2002; Grollman et al., 2007; de Jonge and Vanrenterghem, 2008). BEN is an endemic familial but not inherited chronic renal disease, which is frequently accompanied by urothelial carcinoma of the upper urinary tract (Stefanovic et al., 2007; Miyazaki and Nishiyama, 2017). The disease is prevalent in the endemic farming villages along the tributaries of the Danube river (Stiborova et al., 2016). It has been estimated that almost 25,000 people have caught this disease, and nearly 100,000 people are still at risk (Bamias and Boletis, 2008; Pavlovic, 2013a).

Several hypotheses on the etiology of BEN have been projected in the past decades, including mycotoxins, phytotoxins, heavy 
TABLE 2 | Contents of Aristolochic acids in Chinese patent medicine (CPM).

\begin{tabular}{|c|c|c|c|c|}
\hline Name & AAs & Content & Detection method & Specific herbs in CPM \\
\hline Bu fei e jiao tang (Kuo et al., 2010) & AAl, $\|$ & $\begin{array}{l}\text { AAl: } 119.674 \\
\text { AAll: } 6.802\end{array}$ & LC/MS & Herba Aristolochiae Mollissimae \\
\hline Bi yan ling pian (Zhang, 2017) & AAl & - & HPLC & Radix et Rhizoma Asari \\
\hline Bi yan pian (Guan et al., 2005) & AAl & 3.230 & HPLC & Radix et Rhizoma Asari \\
\hline Chun yang zheng qi wan (Ye et al., 2003) & AAl & 280 & HPLC & Caulis Aristolochiae Manshuriensis \\
\hline Chuan xiong cha tiao ke li (Wei et al., 2005) & AAl & + & LC/MS & Caulis Aristolochiae Manshuriensis \\
\hline Chuan xiong cha tiao san (Kuo et al., 2010) & AAl & - & LC/MS & Caulis Aristolochiae Manshuriensis \\
\hline Chuan xiong cha tiao wan (Ye et al., 2003) & AAl & 140 & HPLC & Caulis Aristolochiae Manshuriensis \\
\hline Dao chi san (Wu et al., 2009) & AAl & 357 & HPLC & Caulis Aristolochiae Manshuriensis \\
\hline Dao chi wan (Wei et al., 2005) & AAl & - & LC/MS & Caulis Akebiae \\
\hline Dang gui si ni tang (Ruan et al., 2012) & AAl & 321.45 & HPLC & Medulla Tetrapanacis \\
\hline Da huang qing wei wan (Shu et al., 2016) & AAl & 0-0.08 & SPE-HPLC & Caulis Akebiae \\
\hline Er shi jiu wei neng xiao san (Zhang et al., 2013a) & AAl & $2.69-3.71$ & HPLC & Fructus Aristolochiae \\
\hline Er shi wu wei Iv rong hao wan (Chen et al., 2009) & AAl & $99-114$ & HPLC & Fructus Aristolochiae \\
\hline Er shi wu wei shan hu wan (Liu et al., 2015) & AAl & - & HPLC, RP-HPLC & Radix Aucklandiae \\
\hline Er shi wu wei shan hu wan (Luo, 2013) & AAl & 52.5 & HPLC & Radix Aucklandiae \\
\hline Er shi wu wei song shi jiao nang (Tan et al., 2005) & AAl & $0.020-0.030$ & HPLC & Fructus Aristolochiae \\
\hline Er tong qing fei wan (Wei et al., 2005) & AAl & - & LC/MS & Radix et Rhizoma Asari \\
\hline Fu fang nan xing zhi tong gao (Yin et al., 2009) & AAl & - & UPLC & Radix et Rhizoma Asari \\
\hline Fu fang quan shen pian (Pang and Qu, 2015) & AAl & $0.29-1.02$ & HPLC & Herba Aristolochiae Mollissimae \\
\hline Gan lu xiao du wan (Chen and Xie, 2004; Zhu et al., 2006) & AAl, $\|$ & $\begin{array}{l}\text { AAl: } 60-230 \\
\text { AAll: } 370-400\end{array}$ & RP-HPLC & Caulis Aristolochiae Manshuriensis \\
\hline Gan te ling jiao nang (Wei et al., 2007) & AAl & - & HPLC & Radix et Rhizoma Asari \\
\hline Gu ben qu feng ke li (Yu et al., 2011a; Yu et al., 2011b) & AAl & - & HPLC & Radix et Rhizoma Asari \\
\hline Guan xin su he di wan (Li et al., 2006; Yuan and Zhang, 2016) & AAl & $148-993$ & HPLC & Radix Aristolochiae \\
\hline Guan xin su he jiao nang (Wei et al., 2005; Li et al., 2006) & AAI, II, IIIa, IVa & $\begin{array}{c}\text { AAl: 183-516 } \\
\text { AA-II:+ } \\
\text { AA-IIla:+ } \\
\text { AA-IVa:+ }\end{array}$ & LC/MS & Radix Aristolochiae \\
\hline $\begin{array}{l}\text { Guan xin su he wan (Li et al., 2006; Wu, 2006; Jiang et al., } \\
\text { 2007; Yuan et al., 2007a; Yuan et al., 2007b; Yuan et al., 2008) }\end{array}$ & AAI, ॥ & $\begin{array}{l}\text { AAl: } 48.500-426 \\
\text { AAll: } 64.700-65.200\end{array}$ & RP-HPLC & Radix Aristolochiae \\
\hline Han shi bi ke li (Kang and Li, 2008) & AAl & - & HPLC & Radix et Rhizoma Asari \\
\hline Jian gu shu jin pian (Huang et al., 2009) & AAl & - & HPLC & Radix et Rhizoma Asari \\
\hline Jiu wei qiang huo ke li (Guan et al., 2005) & AAl & 1.920 & RP-HPLC & Radix et Rhizoma Asari \\
\hline Liu jing tou tong tablet (Huang and Zhu, 2015) & AAl & - & SPE-HPLC & Radix et Rhizoma Asari \\
\hline $\begin{array}{l}\text { Long dan xie gan wan (Ye et al., 2003; Liu et al., 2005; } \\
\text { Wei et al., 2005; Shen et al., 2008) }\end{array}$ & $\begin{array}{l}\text { AAl, II, IIIa, } \\
\text { IVa,7-OH-AAI }\end{array}$ & $\begin{array}{c}\text { AAl: 30-253 } \\
\text { AAll: 44, } \\
\text { AAllla: + } \\
\text { AA-IVa: + } \\
\text { 7-OH-AAl: + }\end{array}$ & HPLC; LC/MS & Caulis Aristolochiae Manshuriensis \\
\hline & AAI, II, & - & UHPLC-MS/MS & Caulis Akebiae \\
\hline Long dan xie gan ke li (Wei et al., 2005) & $\begin{array}{l}\text { AAl, II, IIIa, } \\
\text { IVa,7-OH-AAI }\end{array}$ & - & LC/MS & Caulis Akebiae \\
\hline Ma huang zhi sou wan (Zhou et al., 2015) & AAl & $0.070-0.210$ & SPE-HPLC & Radix et Rhizoma Asari \\
\hline Pai shi ke li (Liu et al., 2005) & AAl, $\|$ & $\begin{array}{l}\text { AAl: } 4 \\
\text { AAll: } 4\end{array}$ & $\begin{array}{l}\text { SPE-HPLC } \\
\text { HPLC }\end{array}$ & Caulis Akebiae \\
\hline Qing nao zhi tong jiao nang (Li et al., 2009) & AAl & - & HPLC & Radix et Rhizoma Asari \\
\hline Qing ning wan (Ye et al., 2003) & AAl & 100 & HPLC & Caulis Aristolochiae Manshuriensis \\
\hline $\begin{array}{l}\text { Qing lin ke li (Yuan et al., 2007a; Yuan et al., 2007b; } \\
\text { Yuan et al., 2008) }\end{array}$ & $\begin{array}{l}\text { AAI, II, IVa;AL- } \\
\text { IV,AL-IVa }\end{array}$ & $\begin{array}{c}\text { AAl: } 114-184 \\
\text { AAll: } 56.200-62.400 \\
\text { AAIVa: } \\
\text { 40.800-58.200 } \\
\text { ALIV: } 52.500 \\
\text { ALIVa: } 32.500-160\end{array}$ & $\begin{array}{l}\text { HPLC } \\
\text { LC/MS }\end{array}$ & Caulis Akebiae \\
\hline Qi wei hong hua shu sheng wan (Wei et al., 2011) & AAl & $241-385$ & HPLC & Fructus Aristolochiae \\
\hline Qing xue nei xiao wan (Gan et al., 2013) & AAl & + & $\begin{array}{l}\text { HPLC } \\
\text { LC/MS }\end{array}$ & Caulis Akebiae \\
\hline Ru mo zhen tong jiao nang (Xue, 2015) & AAl & - & HPLC & Radix et Rhizoma Asari \\
\hline Shen nong she yao jiu (Qiu et al., 2018) & AAl & + & HPLC & Aristolochia fordiana \\
\hline Tiao gu pian (Lin et al., 2014) & AAl & $2.860-6.250$ & HPLC & Radix et Rhizoma Asari \\
\hline Wan tong jin gu pian (Tian and Wang, 2007) & AAl & $2.403-4.779$ & RP-HPLC & Radix et Rhizoma Asari \\
\hline Wu wei zha xun wan (Ni and Yang, 2012) & AAl & 260-280 & HPLC & Fructus Aristolochiae \\
\hline
\end{tabular}


TABLE 2 | Continued

\begin{tabular}{|c|c|c|c|c|}
\hline Name & AAs & Content & Detection method & Specific herbs in CPM \\
\hline Xiao feng zhi yang ke li (Zhang and Wang, 2012) & AAl & - & LC-MS & Caulis Akebiae \\
\hline Xiao qing long ke li (Guan et al., 2005) & AAl & 2.86 & RP-HPLC & Radix et Rhizoma Asari \\
\hline Xiao qing long tang (Kuo et al., 2010) & AAl & 0.194 & LC/MS & Radix et Rhizoma Asari \\
\hline Xiao Zhong zhi tong ding (Tang et al., 2012; He et al., 2013) & AAl & + & $\begin{array}{l}\text { LC-MS/MS, } \\
\text { SPE-HPLC }\end{array}$ & Radix et Rhizoma Asari \\
\hline Xiao Zhong zhi tong ting (Tang et al., 2012; He et al., 2013) & AAl & + & HPLC & Radix et Rhizoma Asari \\
\hline Xin ma zhi ke ke li (Chen et al., 2007) & AAl & - & HPLC & Radix et Rhizoma Asari \\
\hline Xin qin ke li (Ge et al., 2010) & AAl & - & HPLC, SPE-HPLC & Radix et Rhizoma Asari \\
\hline Xin sheng ke li (Ren et al., 2010) & AAl & - & HPLC & Radix et Rhizoma Asari \\
\hline Xi xin pei fang ke li (Pan and Gan, 2009) & AAl & - & LC-MS/MS & Radix et Rhizoma Asari \\
\hline Yang xue qing nao ke li (Li et al., 2007) & AAl & - & HPLC, LC-MS & Radix et Rhizoma Asari \\
\hline Yang yin jiang ya jiao nang (Ran et al., 2016) & AAl & $1129-1458$ & HPLC & Radix Aristolochiae \\
\hline Yi shen juan bi wan (Wang et al., 2017) & AAl & - & HPLC & Herba Aristolochiae Mollissimae \\
\hline Zhui feng tou gu capsule (Lv, 2015) & AAl & - & HPLC & Radix et Rhizoma Asari \\
\hline Zhu sha lian jiao nang (Chen, 2003) & AAl & $1160-4521$ & HPLC & Radix Aristolochiae Cinnabarinae \\
\hline
\end{tabular}

The unit for quantitative data is $\mu \mathrm{g} / \mathrm{g}$.

metals, viruses, trace element deficiencies, and AAs (Stefanovic et al., 2006; Grollman et al., 2007; De Broe, 2012). Among these, the evidence is strongest for inadvertent chronic consumption of food contaminated with AAs leading to BEN (Grollman et al., 2007; De Broe, 2012; Bui-Klimke and Wu, 2014). Researchers assume that the BEN patients might be exposed to toxic AAs through consuming food prepared from flour contaminated with the seeds of the plants of Aristolochia family, which grow abundantly as weeds in the endemic regions (Ivic, 1969; Hranjec et al., 2005; Jelakovic et al., 2012; Grollman, 2013; Jelakovic et al., 2015b). Moreover, molecular agricultural and food chemistry investigations have been carried out to trace other possibilities on how AAs enter the human food chain. Studies have demonstrated that some crops could uptake and bioaccumulate AAs from the Aristolochia species-grown soil and water. Therefore, prolonged intake of food prepared from these crops can also result in BEN (Pavlovic et al., 2013b; Chan et al., 2016; Li et al., 2016; Gruia et al., 2018). In recent years, the definitive link between BEN and AAs has been found. AA-derived DNA adducts and hallmark $A \rightarrow T$ transversions have been detected in renal cortical and urothelial malignant tissues obtained from BEN patients (Grollman et al., 2007; Jelakovic et al., 2012).

\section{Aristolochic Acid-Induced Urothelial Carcinoma}

Apart from nephrotoxicity, AAs have also been implicated in the genesis of UTUC, which is a rare subset of urothelial malignancies occurring in the renal pelvis and upper ureter. UTUC has been so far principally correlated to AA intoxication (Miyazaki and Nishiyama, 2017). At first, scientists found progressive urothelial atypia and atypical hyperplasia in the tissue samples of Belgian patients diagnosed with slimming pill-induced nephrotoxicity (Cosyns et al., 1994a; Cosyns et al., 1994b). Subsequently, urothelial carcinoma localized in the upper urinary tract was observed in almost half of the AAN patients (Nortier et al., 2000). AA-derived DNA adducts and TP53 mutations were also found in the ureteric tissues (Cosyns et al., 1999; Lord et al., 2001), which indicated the carcinogenic potential of AAs on the urothelium. In addition, the prevalence of UTUC is extraordinarily high in BEN patients (Colin et al., 2009; Patel et al., 2014; Soria et al., 2017). The data on AA-derived DNA adducts and $A \rightarrow T$ transversions further corroborated the relationship between AAs and BEN-associated urothelial tumor (Arlt et al., 2002; Arlt et al., 2007; Schmeiser et al., 2012).

Moreover, the trend of urothelial cancer among the patients diagnosed with end-stage renal disease has been reduced with the decreased consumption of AA-containing products (Wang et al., 2014a; Wang et al., 2014b). In 2002 and 2012, the World Health Organization International Agency for Research on Cancer (IARC) classified AAs as group I carcinogen according to the available strong evidence that AA-specific DNA adducts and TP53 mutations were found in humans exposed to materials obtained from plant species containing AAs (IARC, 2002; IARC, 2012). However, despite a high mutagenic and carcinogenic potential, herbal remedies and products containing AAs are still used in Asia contributing to a high incidence of urothelial carcinoma (Chen et al., 2012; Yang et al., 2014; Sun et al., 2015).

Most cases of AA-induced UTUC are found during AAN inspections. Initially, only mild to moderate urothelial atypia and atypical hyperplasia were observed (Cosyns et al., 1994a). Subsequently, overwhelming disseminated pelvicalyceal urothelial atypia, malignant transformation, and/or multifocal flat transitional cell carcinoma mostly localized in the upper urinary tract were shown (Cosyns et al., 1994b; Cosyns et al., 1999). Usually, these tumors have a high mortality rate. The urothelial carcinomas are mainly of synchronous bilateral or metachronous contralateral type and are related to the cumulative exposure of AAs (Chen et al., 2013; Sun et al., 2015). In addition, AA-derived DNA adducts and TP53 mutations are clinically meaningful to explore the involvement of AAs in UTUC (Chen et al., 2012; Chen et al., 2013; Aydin et al., 2014; Yang et al., 2014; Sun et al., 2015).

\section{Other Adverse Effects Induced by Aristolochic Acids}

Besides UTUC, AA-mutational signatures have also been detected in other types of cancer, which indicates that AAs also display carcinogenic potentials in other organs (Rosenquist 
and Grollman, 2016). Clinically, patients with hepatitis B virus infection are presumed to have a higher risk of hepatocellular carcinoma if they consume AA-containing herbs (Chen et al., 2018). Genomic heterogeneity analyses provide strong evidence that AAs potentially contribute to the development of liver cancer (Poon et al., 2013; Lin et al., 2017). Recently, a specific mutational signature of AA exposure has been exhibited in whole exome sequencing of hepatocellular carcinomas, suggesting a plausible conclusion that AAs and their derivatives might be one of the culprits triggering liver cancer in Asia (Totoki et al., 2014; Letouze et al., 2017; Ng et al., 2017; Nault and Letouze, 2019). AAs can also affect the initiation and/or progression of renal cell carcinoma (Scelo et al., 2014; Jelakovic et al., 2015a; Hoang et al., 2016) or bladder urothelial tumor (Lemy et al., 2008; Poon et al., 2015; Sun et al., 2015).

More carcinogenic potentials and/or toxic effects of AAs are explored in animal studies. High risk of tumor occurrence in the fore-stomach, ear duct, small intestine, kidney, urothelial tract, liver, bladder, and/or subcutaneous regions were observed in mice, rats, and/or canines after AA administration (Mengs, 1982; Mengs, 1988; Schmeiser et al., 1990; Wang et al., 2011; Wang et al., 2018b; Jin et al., 2016). Renal toxicity of AAs is observed in both mice and rats after repeat dose (Mengs, 1987; Mengs and Stotzem, 1993). Furthermore, aristolochic acid I (AAI)-induced gastrotoxicity characterized by fore-stomach damage presents prior to renal injury ( $\mathrm{Pu}$ et al., 2016). In addition, AAI could induce apoptotic cell death in the ovaries and testis of mice and cause severe reduction of organ size and weight (Kwak et al., 2014; Kwak and Lee, 2016).

\section{TOXICOLOGICAL PROPERTIES OF ARISTOLOCHIC ACIDS}

\section{Mutational Signature of Aristolochic Acids}

As mentioned above, AAs are conversed to reactive intermediates (aristolactam nitrenium ion) and bind to purines in DNA to form covalent DNA adducts. The adducts of AAs with DNA are highly persistent in human tissues (Schmeiser et al., 2014) due to the lack of recognition and/or processing by global genome nucleotide excision repair (Lukin et al., 2012; Sidorenko et al., 2012). Without effective DNA repair, predominant $A \rightarrow T$ transversions enriched on the nontranscribed gene strand in the TP53 tumor suppressor gene could form in high frequency (Moriya et al., 2011; Hoang et al., 2013). The TP53 mutations and formation of AA-derived DNA adducts are considered as biomarkers for the assessment of AA exposure (Slade et al., 2009; Stiborova et al., 2017). Mutated base adenine accounts for more than half of the mutational spectra detected in the specimens of AAN and AA-induced UTUC patients (Lord et al., 2004; Chen et al., 2012; Jelakovic et al., 2012; Hoang et al., 2013; Castells et al., 2015). Besides $\mathrm{A} \rightarrow \mathrm{T}$ transversions, $\mathrm{C} \rightarrow \mathrm{T}$ transversions also occur in a high frequency. Multiple mutations are mainly found in the TP53 hotspot region of exons 5-8, as well as exons 4 and 10 (Moriya et al., 2011; Aydin et al., 2017). In animal studies, $\mathrm{A} \rightarrow \mathrm{T}$ transversions were observed in the activating positions in $\mathrm{H}$-ras of rats treated with AAs (Wang et al., 2011). Further, RNAs modified by AAs were at much higher frequencies than DNA (Leung and Chan, 2015).

\section{Biotransformation of Aristolochic Acids}

In phase I biotransformation reaction, AAs are first transformed to $\mathrm{N}$-hydroxyaristolactams (AL-NOHs) through nitroreduction reaction. After that, they are converted to aristolactam-nitrenium, which is an electrophilic cyclic aristolactam-nitrenium ion with delocalized positive charges. They preferentially bind to the exocyclic amino groups of purine bases in DNA to form AA-DNA adducts. These adducts can lead to $\mathrm{A} \rightarrow \mathrm{T}$ transversions and elicit renal disease and cancers (Stiborova et al., 2008b; Stiborova et al., 2008c). Both microsomal and cytosolic phase I enzymes participate in catalyzing the activation of AAs to form AA-DNA adducts consisting of 7-(deoxyadenosin- $\mathrm{N}^{6}-\mathrm{yl}$ ) aristolactam I (dA-AAI), 7-(deoxyguanosin- $\mathrm{N}^{2}$-yl) aristolactam I (dG-AAI), 7-(deoxyadenosin- $\left.\mathrm{N}^{6}-\mathrm{yl}\right)$ aristolactam II (dA-AAII), and 7-(deoxyguanosin- $\mathrm{N}^{2}$-yl) aristolactam II (dG-AAII) (Stiborova et al., 2005; Stiborova et al., 2008a), in which dA-AAI and dA-AAII persist for an exceptionally long time in the lesions (Lukin et al., 2012; Schmeiser et al., 2014). The dA adducts are also significantly more mutagenic than the dG adducts (Attaluri et al., 2010). According to the results from in vitro studies, among the cytosolic reductases, $\mathrm{NAD}(\mathrm{P}) \mathrm{H}$ :quinone oxidoreductase (NQO1) plays the most important role in activation of AAs in the liver and kidney. In human renal microsomes, NADPH : CYP reductase (CPR) is proven to be more effective in activating AAs, and prostaglandin $\mathrm{H}$ synthase (cyclooxygenase, $\mathrm{COX}$ ) is also involved in the reductive reaction. In human hepatic microsomes, CYP1A2 contributes maximum in the process, while CYP1A1 exhibits lesser effects and CPR plays a minor role (Stiborova et al., 2005; Stiborova et al., 2008a). Currently, the roles of the hydroxyl group on amino acids present in the active center of CYP1A1 and CYP1A2 on nitroreduction of AAs have been verified using a site-directed mutagenesis approach (Milichovsky et al., 2016). It is assumed that the genes of enzymes existing in variant forms or showing polymorphisms may be one of the factors affecting the individual's susceptibility to AAs (Stiborova et al., 2008a). Additionally, phase II metabolisms formed by sulfation are reported to readily produce AA-DNA adducts (Sidorenko et al., 2014). It has been predicted that following reductive reactions, AL-NOHs may serve as substrates for sulfotransferases (SULTs) and convert them to $\mathrm{N}$-sulfated esters, which react more efficiently with DNA (Sidorenko et al., 2014; Hashimoto et al., 2016). Among the SULTs tested, SULT1A1 and SULT1B1 displayed more activity than the other subtypes (Meinl et al., 2006; Sidorenko et al., 2014). The sulfate conjugates could be transported out of the liver via MRP membrane transporters and transferred into the kidney via organic anionic transporters (OAT), thereby inducing kidney damage (Chang et al., 2017). However, conflicting results have been observed in some other studies (Stiborova et al., 2011; Arlt et al., 2017) (Figure 2).

On the other hand, detoxification of AAI happens at the same time when it exerts mutagenic and cytotoxic potentials. Some studies have mentioned that N-hydroxyaristolactam I could also competitively rearrange to 7-hydroxyaristolactam I or further reductive production of aristolactam I (ALI) (Stiborova et al., 
<smiles>O=C(O)c1cc2c(c3c1c([N+](=O)[O-])cc1c(Br)cccc13)OCO2</smiles>
Aristolochic acid I: $\mathrm{R}=\mathrm{O} \mathrm{CH}$,
Aristolochic acid il: $\mathrm{R}=\mathrm{H}$

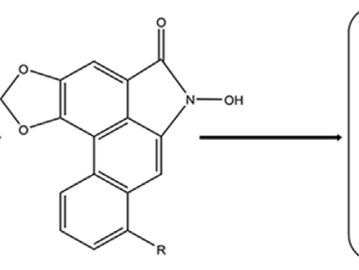

N-hydroxyaristolactam

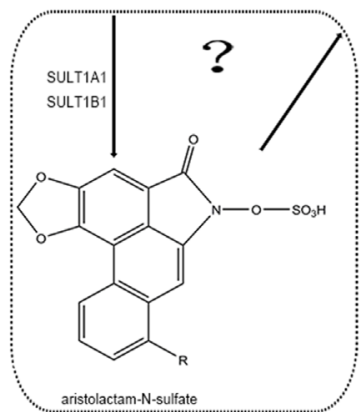

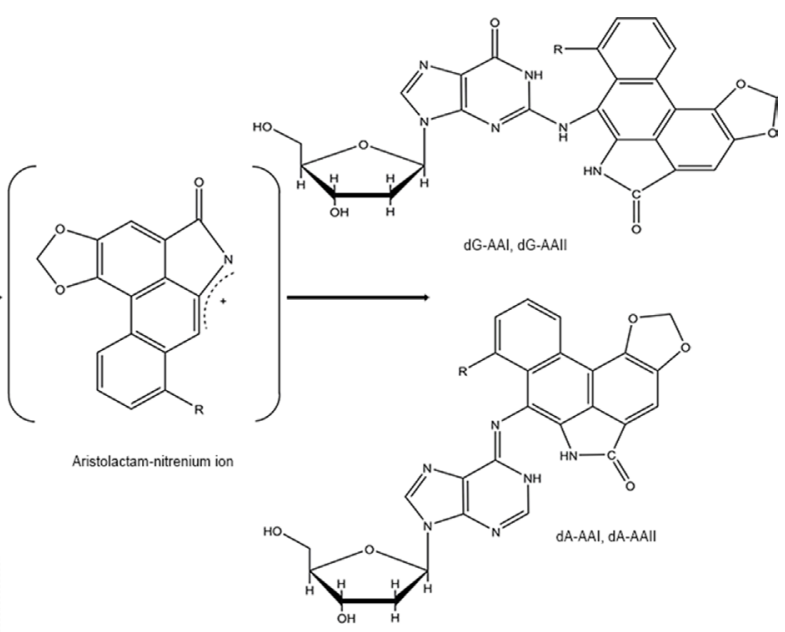

FIGURE 2 | Proposed pathway for metabolic activation of AAl and AAll.

2008b; Stiborova et al., 2008c), which shows a lower capacity to form AAI-DNA adducts (Dong et al., 2006). In addition, oxidation of AAI to a lesser toxic 8-hydroxyaristolochic acid I (aristolochic acid Ia, AAIa) is also suggested to be a detoxifying pathway of AAI (Stiborova et al., 2008b; Stiborova et al., 2008c). The O-demethylated metabolites of AAI, conjugated metabolites of AAIa, are found to be excreted in the urine of AA-treated rats (Chan et al., 2007). Hepatic microsomal cytochrome P450, especially CYP1A subfamily (CYP1A1 and CYP1A2), has been found to play a critical role in suppressing the carcinogenic and nephrotoxic effects of AAI (Xiao et al., 2008; Stiborova et al., 2009; Rosenquist et al., 2010; Stiborova et al., 2012; Stiborova et al., 2015; Dracinska et al., 2016). Therefore, the CYP1A1 and 1A2 play a dual role by partly regulating the balance between reductive activation and oxidative detoxification of AAI (Figure 3). However, the analogical mechanism has not been observed in AAII yet because AAII shows much lower amenability to oxidation than AAI (Martinek et al., 2017).

\section{Specific Organic Anion Transporters for Aristolochic Acids}

The nephrotoxic damage of AAs selectively targets the proximal tubules, indicating that the toxins may specifically accumulate in these tissues. The proximal tubules take charge in the secretion and reabsorption of xenobiotics or their metabolites through several particular transporters. OAT family, a group of multispecific membrane transport proteins, contributes to the renal handling of negatively charged drugs and other organic compounds. Indeed, AAI as a low molecular weight organic anion with an anionic carboxyl group and a hydrophobic part possesses the chemical characteristics of a substrate for OAT. OAT family is, therefore, considered to be one of the pivotal determinants mediating the accumulation of AAI into the renal proximal tubules (Dickman et al., 2011). Many investigations have verified OATs, especially OAT1 and OAT3, in the basolateral membrane of the proximal tubules facilitating the uptake of AAI by renal cells, which at least partly lead to site-selective AAI-induced nephrotoxicity (Bakhiya et al., 2009; Dickman et al., 2011; Xue et al., 2011; Baudoux et al., 2012). In addition, the phase II metabolite of AAI, sulfate-conjugated AL-I (sulfonyloxyaristolactam, AL-I-NOSO ${ }_{3}$ ) is reported to be transported into kidney via OAT1, OAT3, and OAT4 (Chang et al., 2017).

\section{Other Mechanisms Involved in Aristolochic Acid-Induced Adverse Reactions}

The chemical structures of AAs are considered as critical determinants of their toxic effects. According to the current knowledge, AAI is solely responsible for nephrotoxicity (Shibutani et al., 2007) and has more cytotoxicity than AAII (Balachandran et al., 2005). On the other hand, AAII may show higher or similar genotoxic and carcinogenic potentials as AAI (Shibutani et al., 2007; Xing et al., 2012). In reductive reactions, NQO1 is more effective in activating of AAI than AAII (Martinek et al., 2011), and the extent of AAI-DNA adducts is much higher than that of AAIIDNA adducts in most in vitro enzymatic systems (Schmeiser et al., 1997). During phase II metabolism, ALI-DNA adducts are also formed more efficiently than ALII-DNA adducts in SULT1B1 (Sidorenko et al., 2014). In addition, similar CYP-mediated oxidative detoxification reactions of AAI are not observed in AAII (Martinek et al., 2017). The difference on enzymatic conversion of AAI and AAII is considered to relate to their chemical structures. 
<smiles>[R]Oc1cccc2c1cc([N+](=O)[O-])c1c(C(=O)O)cc3c(c12)OCO3</smiles><smiles>COc1cccc2c1cc1c3c(cc4c(c32)OCO4)C(=O)N1O</smiles><smiles>COc1cccc2c1c(O)c1c3c(cc4c(c32)OCO4)C(=O)N1</smiles>

Aristolochic acid I

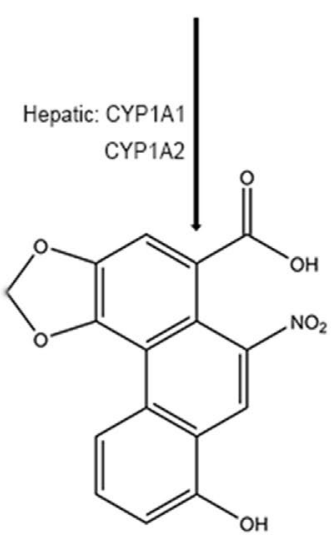

Aristolochic acid la
N-hydroxyaristolactam I<smiles></smiles>

Aristolactam I

FIGURE 3 | Proposed pathway for metabolic detoxication of AAI.

In recent years, more than 30 microRNAs differentially expressed in patients exposed to AAs have been explored, which might improve the understanding of the pathogenesis of AA-related renal disease and cancer. It has been speculated that FGFR3, Akt, mucin type O-glycan biosynthesis, ECM receptor interaction pathways, and other biological mechanisms might be involved in the occurrences of AAN, BEN, and/or AA-induced UTUC (Tao et al., 2015; Lv et al., 2016; Popovska-Jankovic et al., 2016). Meanwhile, $15 \%$ of the 417 detectable miRNAs have been found to be altered by AAs in rats (Li et al., 2015). During exome sequencing of genes in DNA samples from BEN patients, possible deleterious/damaging variants-CELA1, HSPG2, and KCNK5are detected. These genes could encode proteins connected to the process of angiogenesis (Toncheva et al., 2014), which is tightly correlated with BEN and UTUC (Jankovic-Velickovic et al., 2012).

Some studies have focused on the contributions of innate and adaptive immunity in the progression of AAN (Sato et al., 2004; Pozdzik et al., 2010). In the kidney specimens, interstitial inflammatory infiltration is dramatically observed in the tubulointerstitial lesions, and massive infiltration of macrophages and $\mathrm{T}$ and $\mathrm{B}$ lymphocytes is demonstrated in the medullary rays and outer medullae, implying the onset of immune response (Pozdzik et al., 2010). Animal study has suggested that AAs increase the proportion of myeloid CD11 $\mathrm{b}^{\text {high }} \mathrm{F} 4 / 80^{\text {mid }}$ and decrease their counterpart. $\mathrm{CD} 4^{+}$and $\mathrm{CD} 8^{+} \mathrm{T}$-cells could provide protection against AA-induced acute tubular necrosis (Baudoux et al., 2018).
However, this view is still debatable as AAI is also reported to damage the epithelial cells lining the proximal renal tubule due to direct toxic effects instead of immune actions (Yi et al., 2018).

Meanwhile, AAs could cause increased oxidative stress leading to impaired renal function. AAI elicits oxidative stress-related DNA damage through depleting antioxidant glutathione in the human renal proximal tubular cells (Yu et al., 2011a; Yu et al., 2011b) and induces increased reactive oxygen species (ROS) and tubular apoptosis via decreasing nitric oxide availability in mice (Decleves et al., 2016).

Inflammatory and fibrotic pathways and dynamic changes in fatty acid, phospholipid, and glycerolipid metabolisms are all linked to AAN (Zhao et al., 2015). Additionally, mitogenactivated protein kinase (MAPK)-related signaling pathways are considered to be associated with nephrotoxicity and reproductive toxicity of AAI. AAI could upregulate the expression of phosphoERK1/2 in cells, which contributes to ROS generation (Yu et al., 2011a; Yu et al., 2011b). AAs also activate JNK signaling pathway and elicit the overexpression of TGF-1, which is critically involved in the pathogenesis of AAN (Rui et al., 2012). Interestingly, some other studies have described that AAI inhibits Akt and/or ERK1/2 phosphorylation, impedes relevant apoptosis, and causes severe injury resulting in the development of ovarian and testis in mice (Kwak et al., 2014; Kwak and Lee, 2016; Yu et al., 2011b). Besides, NFkb, aryl hydrocarbon receptor, and cell cycle signaling are also modulated in the kidneys of AA-treated mice (Arlt et al., 2011). 
In addition, the loss of functional TASK-2 channels may indirectly increase the susceptibility to the toxic effects of AAs (Veale and Mathie, 2016). The decrease in pro-apoptotic protein Bax can predict the development of AA-induced UTUC (JankovicVelickovic et al., 2011).

\section{CONCLUSION}

AAs have been recognized as a group of potent nephrotoxin and carcinogen. The consumption of AA-containing foods can cause permanent kidney injury, end-stage renal disease, and even UTUC. AA-derived DNA adducts are recognized as specific biomarkers for the assessment of AA exposure. A characteristically mutational signature of $A \rightarrow T$ transversions observed in the tumor tissues also implies the exposure of AAs. So far, the underlying etiological mechanisms of AA-induced renal disease and UTUC have been preliminarily revealed, although the detailed mechanisms are far from being completely understood. In addition, various enzymes, organic anion transporters, and molecular mechanisms might be involved in AA-induced damages. Therapy for AAN and AA-induced UTUC remains a serious challenge. AA-related adverse events are still widely reported, especially in the Asian and Balkan regions. AAs have now been listed as group I carcinogen by IARC (IARC, 2002; IARC, 2012). The US Food and Drug Administration and regulatory

\section{REFERENCES}

Abdullah, R., Diaz, L. N., Wesseling, S., and Rietjens, I. M. (2017). Risk assessment of plant food supplements and other herbal products containing aristolochic acids using the margin of exposure (MOE) approach. Food Addit. Contam. Part A Chem. Anal. Control Expo. Risk Assess. 34 (2), 135-144. doi: 10.1080/ 19440049.2016.1266098

Ardalan, M. R., Khodaie, L., Nasri, H., and Jouyban, A. (2015). Herbs and hazards: risk of aristolochic acid nephropathy in Iran. Iran J. Kidney Dis. 9 (1), 14-17. doi: http://dx.doi.org/

Arlt, V. M., Ferluga, D., Stiborova, M., Pfohl-Leszkowicz, A., Vukelic, M., Ceovic, S., et al. (2002). Is aristolochic acid a risk factor for Balkan endemic nephropathy-associated urothelial cancer? Int. J. Cancer 101 (5), 500-502. doi: 10.1002/ijc.10602

Arlt, V. M., Meinl, W., Florian, S., Nagy, E., Barta, F., Thomann, M., et al. (2017). Impact of genetic modulation of SULT1A enzymes on DNA adduct formation by aristolochic acids and 3-nitrobenzanthrone. Arch. Toxicol. 91 (4), 1957-1975. doi: 10.1007/s00204-016-1808-6

Arlt, V. M., Stiborova, M., vom Brocke, J., Simoes, M. L., Lord, G. M., Nortier, J. L., et al. (2007). Aristolochic acid mutagenesis: molecular clues to the aetiology of Balkan endemic nephropathy-associated urothelial cancer. Carcinogenesis 28 (11), 2253-2261. doi: 10.1093/carcin/bgm082

Arlt, V. M., Zuo, J., Trenz, K., Roufosse, C. A., Lord, G. M., Nortier, J. L., et al. (2011). Gene expression changes induced by the human carcinogen aristolochic acid I in renal and hepatic tissue of mice. Int. J. Cancer 128 (1), 21-32. doi: 10.1002/ ijc. 25324

Attaluri, S. R., Bonala, R., Yang, I. Y., Lukin, M. A., Wen, Y., Grollman, A. P., et al. (2010). DNA adducts of aristolochic acid II: total synthesis and site-specific mutagenesis studies in mammalian cells. Nucleic Acids Res. 38 (1), 339-352. doi: 10.1093/nar/gkp815

Aydin, S., Ambroise, J., Cosyns, J. P., and Gala, J. L. (2017). TP53 mutations in p53negative dysplastic urothelial cells from Belgian AAN patients: new evidence for aristolochic acid-induced molecular pathogenesis and carcinogenesis. Mutat. Res. 818, 17-26. doi: 10.1016/j.mrgentox.2017.03.003 authorities of some other countries have issued alerts against the use and import of products containing AAs (Zhang et al., 2019). However, in China and some countries, products containing herb preparations from Aristolochia and Asarum are still used, and food contaminated by AAs cause health problems in some countries (Ioset et al., 2003; Wooltorton, 2004; Hsieh et al., 2008; Michl et al., 2013; Ardalan et al., 2015; Cachet et al., 2016; Abdullah et al., 2017). Therefore, the use of AA-containing herbal medications and consumption of food contaminated by AAs may still impose high risk, and hence, more strict precautions should be taken to protect the public from AA exposure.

\section{AUTHOR CONTRIBUTIONS}

$\mathrm{JH}, \mathrm{ZX}$, and JL are the major writers of the manuscript. YZ has drawn the pictures. AL has overseen the writing.

\section{FUNDING}

This work was supported by grants from the National Science and Technology Major Project (2015ZX09501004-003-001 and 2018ZX09101002-003), Beijing Science and Technology Projects (Z151100000115012 and Z161100004916025), and China Academy of Chinese Medical Sciences Foundation (ZZ10-025 and ZZ12-001).

Aydin, S., Dekairelle, A. F., Ambroise, J., Durant, J. F., Heusterspreute, M., Guiot, Y., et al. (2014). Unambiguous detection of multiple TP53 gene mutations in AANassociated urothelial cancer in Belgium using laser capture microdissection. PLoS One 9 (9), e106301. doi: 10.1371/journal.pone.0106301

Bakhiya, N., Arlt, V. M., Bahn, A., Burckhardt, G., Phillips, D. H., and Glatt, H. (2009). Molecular evidence for an involvement of organic anion transporters (OATs) in aristolochic acid nephropathy. Toxicology 264 (1-2), 74-79. doi: 10.1016/j.tox.2009.07.014

Balachandran, P., Wei, F., Lin, R. C., Khan, I. A., and Pasco, D. S. (2005). Structure activity relationships of aristolochic acid analogues: toxicity in cultured renal epithelial cells. Kidney Int. 67 (5), 1797-1805. doi: 10.1111/j. 1523-1755.2005.00277.x

Bamias, G., and Boletis, J. (2008). Balkan nephropathy: evolution of our knowledge. Am. J. Kidney Dis. 52 (3), 606-616. doi: 10.1053/j.ajkd.2008.05.024

Ban, T. H., Min, J. W., Seo, C., Kim, D. R., Lee, Y. H., Chung, B. H., et al. (2018). Update of aristolochic acid nephropathy in Korea. Korean J. Intern. Med. 33 (5), 961-969. doi: 10.3904/kjim.2016.288

Baudoux, T., Husson, C., De Prez, E., Jadot, I., Antoine, M. H., Nortier, J. L., et al. (2018). CD4 ${ }^{+}$and $\mathrm{CD} 8{ }^{+} \mathrm{T}$ cells exert regulatory properties during experimental acute aristolochic acid nephropathy. Sci. Rep. 8 (1), 5334. doi: 10.1038/ s41598-018-23565-2

Baudoux, T. E., Pozdzik, A. A., Arlt, V. M., De Prez, E. G., Antoine, M. H., Quellard, N., et al. (2012). Probenecid prevents acute tubular necrosis in a mouse model of aristolochic acid nephropathy. Kidney Int. 82 (10), 1105-1113. doi: 10.1038/ ki.2012.264

Bhattacharjee, P., Bera, I., Chakraborty, S., Ghoshal, N., and Bhattacharyya, D. (2017). Aristolochic acid and its derivatives as inhibitors of snake venom L-amino acid oxidase. Toxicon 138, 1-17. doi: 10.1016/j.toxicon.2017.08.003

Bui-Klimke, T., and Wu, F. (2014). Evaluating weight of evidence in the mystery of Balkan endemic nephropathy. Risk Anal. 34 (9), 1688-1705. doi: 10.1111/ risa. 12239

Cachet, X., Langrand, J., Bottai, C., Dufat, H., Locatelli-Jouans, C., Nossin, E., et al. (2016). Detection of aristolochic acids I and II in "Chiniy-tref", a traditional medicinal preparation containing caterpillars feeding on Aristolochia trilobata L. 
in Martinique, French West Indies. Toxicon 114, 28-30. doi: 10.1016/j. toxicon.2016.02.013

Castells, X., Karanovic, S., Ardin, M., Tomic, K., Xylinas, E., Durand, G., et al. (2015). Low-coverage exome sequencing screen in formalin-fixed paraffinembedded tumors reveals evidence of exposure to carcinogenic aristolochic acid. Cancer Epidemiol. Biomarkers Prev. 24 (12), 1873-1881. doi: 10.1158/10559965.EPI-15-0553

Chan, W., Luo, H. B., Zheng, Y., Cheng, Y. K., and Cai, Z. (2007). Investigation of the metabolism and reductive activation of carcinogenic aristolochic acids in rats. Drug Metab. Dispos. 35 (6), 866-874. doi: 10.1124/dmd.106.013979

Chan, W., Pavlovic, N. M., Li, W., Chan, C. K., Liu, J., Deng, K., et al. (2016). Quantitation of aristolochic acids in corn, wheat grain, and soil samples collected in serbia: identifying a novel exposure pathway in the etiology of Balkan endemic nephropathy. J. Agric. Food Chem. 64 (29), 5928-5934. doi: 10.1021/acs.jafc.6b02203

Chang, S. Y., Weber, E. J., Sidorenko, V. S., Chapron, A., Yeung, C. K., Gao, C., et al. (2017). Human liver-kidney model elucidates the mechanisms of aristolochic acid nephrotoxicity. JCI Insight 2 (22). doi: 10.1172/jci.insight.95978

Chen, C. H., Dickman, K. G., Huang, C. Y., Moriya, M., Shun, C. T., Tai, H. C., et al. (2013). Aristolochic acid-induced upper tract urothelial carcinoma in Taiwan: clinical characteristics and outcomes. Int. J. Cancer 133 (1), 14-20. doi: $10.1002 / \mathrm{ijc} .28013$

Chen, C. H., Dickman, K. G., Moriya, M., Zavadil, J., Sidorenko, V. S., Edwards, K. L., et al. (2012). Aristolochic acid-associated urothelial cancer in Taiwan. Proc. Natl. Acad. Sci. U. S. A. 109 (21), 8241-8246. doi: 10.1073/pnas.1119920109

Chen, C. J., Yang, Y. H., Lin, M. H., Lee, C. P., Tsan, Y. T., Lai, M. N., et al. (2018). Herbal medicine containing aristolochic acid and the risk of hepatocellular carcinoma in patients with hepatitis B virus infection. Int. J. Cancer. doi: 10.1002/ijc. 31544

Chen, L., and Xie, B. (2004). Determination of the contents of aristolochic acid in Ganluxiaodu Pills by RP-HPLC. J. Zhejiang Chin. Med. Univ. 28 (2), 73-74. doi: 10.16466/j.issn1005-5509.2004.02.045

Chen, J., Li, Y., Meng, S., and Guo, M. (2007). Determination of aristolochic acid in Xinmazhike Granules. Lishizhen Med. Mater. Med. Res. 18 (11), 2725-2726. doi: 10.3969/j.issn.1008-0805.2007.11.068

Chen, Y. (2003). Determination of the contents of aristolochic acid A in Zhushalian Capsule by HPLC. J. Chongqing Med. Univ. 28 (1), 84-86. doi: 10.13406/j.cnki. cyxb.2003.01.027

Chen, Y., Hang, Z., Liu, Y., Liu, Y., Liu, Q., and Yi, J. (2009). Analysis of aristolochic acid A in Ershiwuweiluronghao Pills. Chin. J. Pharm. Anal. 29 (9), 1458-1461. doi: 10.16155/j.0254-1793.2009.09.006

Colin, P., Koenig, P., Ouzzane, A., Berthon, N., Villers, A., Biserte, J., et al. (2009). Environmental factors involved in carcinogenesis of urothelial cell carcinomas of the upper urinary tract. BJU Int. 104 (10), 1436-1440. doi: 10.1111/j.1464410X.2009.08838.x

Cosyns, J. P., Jadoul, M., Squifflet, J. P., De Plaen, J. F., Ferluga, D., and van Ypersele de Strihou, C. (1994a). Chinese herbs nephropathy: a clue to Balkan endemic nephropathy? Kidney Int. 45 (6), 1680-1688. doi: 10.1038/ki.1994.220

Cosyns, J. P., Jadoul, M., Squifflet, J. P., Van Cangh, P. J., and van Ypersele de Strihou, C. (1994b). Urothelial malignancy in nephropathy due to Chinese herbs. Lancet 344 (8916), 188. doi: 10.1016/S0140-6736(94)92786-3

Cosyns, J. P., Jadoul, M., Squifflet, J. P., Wese, F. X., and van Ypersele de Strihou, C. (1999). Urothelial lesions in Chinese-herb nephropathy. Am. J. Kidney Dis. 33 (6), 1011-1017. doi: 10.1016/S0272-6386(99)70136-8

De Broe, M. E. (2012). Chinese herbs nephropathy and Balkan endemic nephropathy: toward a single entity, aristolochic acid nephropathy. Kidney Int. 81 (6), 513-515. doi: 10.1038/ki.2011.428

de Jonge, H., and Vanrenterghem, Y. (2008). Aristolochic acid: the common culprit of Chinese herbs nephropathy and Balkan endemic nephropathy. Nephrol. Dial. Transplant. 23 (1), 39-41. doi: 10.1093/ndt/gfm667

Debelle, F. D., Vanherweghem, J. L., and Nortier, J. L. (2008). Aristolochic acid nephropathy: a worldwide problem. Kidney Int. 74 (2), 158-169. doi: 10.1038/ ki.2008.129

Decleves, A. E., Jadot, I., Colombaro, V., Martin, B., Voisin, V., Nortier, J., et al. (2016). Protective effect of nitric oxide in aristolochic acid-induced toxic acute kidney injury: an old friend with new assets. Exp. Physiol. 101 (1), 193-206. doi: 10.1113/EP085333

Depierreux, M., Van Damme, B., Vanden Houte, K., and Vanherweghem, J. L. (1994). Pathologic aspects of a newly described nephropathy related to the prolonged use of Chinese herbs. Am. J. Kidney Dis. 24 (2), 172-180. doi: 10.1016/S0272-6386(12)80178-8

Dickman, K. G., Sweet, D. H., Bonala, R., Ray, T., and Wu, A. (2011). Physiological and molecular characterization of aristolochic acid transport by the kidney. J. Pharmacol. Exp. Ther. 338 (2), 588-597. doi: 10.1124/jpet.111.180984

Ding, H., Shen, J., Fei, W., Qian, Y., Xie, T., and Liu, Q. (2018). Determination of aristolochic acid A, B, C, D in aristolochia herbs by UPLC-MS/MS. Chin. J. Ethnomed. Ethnopharmacy 27 (18), 38-43.

Dong, H., Suzuki, N., Torres, M. C., Bonala, R. R., Johnson, F., Grollman, A. P., et al. (2006). Quantitative determination of aristolochic acid-derived DNA adducts in rats using 32P-postlabeling/polyacrylamide gel electrophoresis analysis. Drug Metab. Dispos. 34 (7), 1122-1127. doi: 10.1124/dmd.105.008706

Dong, S., Shang, M., Wang, X., Zhang, S., Li, C., and Cai, S. (2009). Chemical constituents isolated from Saruma henryi. J. Chin. Pharm. Sci. 18 (2), 146-150.

Dracinska, H., Barta, F., Levova, K., Hudecova, A., Moserova, M., Schmeiser, H. H., et al. (2016). Induction of cytochromes P450 $1 \mathrm{~A} 1$ and $1 \mathrm{~A} 2$ suppresses formation of DNA adducts by carcinogenic aristolochic acid I in rats in vivo. Toxicology, 344-346, 7-18. doi: 10.1016/j.tox.2016.01.011

Gan, S., Han, T., Liu, H., Shi, X., and Wu, C. (2013). Determination of aristolochic acid A in Qingxueneixiao Pills by LC-MS-MS. Chin. J. Exp. Tradit. Med. Formulae 19 (16), 163-167. doi: 10.11653/syfi2013160163

Ge, X., Zhang, Y., Cai, X., Wu, C., and Wang, H. (2010). Limit test for aristolochic acid A in Xinqin Granules by HPLC. Chin. J. Pharm. 41 (8), 604-606.

Gokmen, M. R., Cosyns, J. P., Arlt, V. M., Stiborova, M., Phillips, D. H., Schmeiser, H. H., et al. (2013). The epidemiology, diagnosis, and management of aristolochic acid nephropathy: a narrative review. Ann. Int. Med. 158 (6), 469477. doi: 10.7326/0003-4819-158-6-201303190-00006

Gold, L. S., and Slone, T. H. (2003). Aristolochic acid, an herbal carcinogen, sold on the web after FDA alert. N. Engl. J. Med. 349 (16), 1576-1577. doi: 10.1056/ NEJM200310163491619

Grollman, A. P. (2013). Aristolochic acid nephropathy: harbinger of a global iatrogenic disease. Environ. Mol. Mutagen. 54 (1), 1-7. doi: 10.1002/em.21756

Grollman, A. P., Shibutani, S., Moriya, M., Miller, F., Wu, L., Moll, U., et al. (2007). Aristolochic acid and the etiology of endemic (Balkan) nephropathy. Proc. Natl. Acad. Sci. U. S. A. 104 (29), 12129-12134. doi: 10.1073/pnas. 0701248104

Gruia, A. T., Oprean, C., Ivan, A., Cean, A., Cristea, M., Draghia, L., et al. (2018). Balkan endemic nephropathy and aristolochic acid I: an investigation into the role of soil and soil organic matter contamination, as a potential natural exposure pathway. Environ. Geochem. Health 40 (4), 1437-1448. doi: 10.1007/ s10653-017-0065-9

Guan, W., Li, X., and Xiao, J. (2005). Determination of the contents of aristolochic acid in Asari Radix et Rhizoma and its preparations by reversible high performance liquid chromatography. Chin. Remedies Clinics 5 (4), 283-285. doi: 10.3969/j.issn.1671-2560.2005.04.013

Han, N., Lu, J., Bi, K., Du, X., Zhou, Y., and Zhou, J. (2008). Assaying of aristolochic acid A in 14 traditional Chinese medicines by RP-HPLC. J. Shenyang Pharm. Univ. 25 (2), 115-118. doi: 10.14066/j.cnki.cn21-1349/r.2008.02.005

Hashimoto, K., Higuchi, M., Makino, B., Sakakibara, I., Kubo, M., Komatsu, Y., et al. (1998). Quantitative analysis of aristolochic acids, toxic compounds, contained in some medicinal plants. J. Ethnopharmacol. 64 (1999), 185-189. doi: 10.1016/S0378-8741(98)00123-8

Hashimoto, K., Higuchi, M., Fau-Makino, B., Makino, B., Fau-Sakakibara, I., Sakakibara I Fau-Kubo, M., Kubo M Fau-Komatsu, Y., Komatsu Y Fau-Maruno, M., et al. (1999). Quantitative analysis of aristolochic acids, toxic compounds, contained in some medicinal plants. J. Ethnopharmacol. 64 (2), 185-189. doi: 10.1016/S0378-8741(98)00123-8

Hashimoto, K., Zaitseva, I. N., Bonala, R., Attaluri, S., Ozga, K., Iden, C. R., et al. (2016). Sulfotransferase-1A1-dependent bioactivation of aristolochic acid I and N-hydroxyaristolactam I in human cells. Carcinogenesis 37 (7), 647-655. doi: 10.1093/carcin/bgw045

He, S., Tang, X., Sang, T., Zhao, X., and Xie, T. (2013). Content determination of aristolochic acid A in Xiaozhongzhitong Tincture by LC-MS/MS. China Pharmacy 24 (20), 1907-1909. doi: 10.6039/j.issn.1001-0408.2013.20.31

Heinrich, M., Chan, J., Wanke, S., Neinhuis, C., and Simmonds, M. S. (2009). Local uses of Aristolochia species and content of nephrotoxic aristolochic acid 1 and 2-a global assessment based on bibliographic sources. J. Ethnopharmacol. 125 (1), 108-144. doi: 10.1016/j.jep.2009.05.028 
Hoang, M. L., Chen, C. H., Chen, P. C., Roberts, N. J., Dickman, K. G., Yun, B. H., et al. (2016). Aristolochic acid in the etiology of renal cell carcinoma. Cancer Epidemiol. Biomarkers Prev. 25 (12), 1600-1608. doi: 10.1158/1055-9965. EPI-16-0219

Hoang, M. L., Chen, C. H., Sidorenko, V. S., He, J., Dickman, K. G., Yun, B. H., et al. (2013). Mutational signature of aristolochic acid exposure as revealed by whole-exome sequencing. Sci. Transl. Med. 5 (197), 197ra102. doi: 10.1126/ scitranslmed.3006200

Hranjec, T., Kovac, A., Kos, J., Mao, W., Chen, J. J., Grollman, A. P., et al. (2005). Endemic nephropathy: the case for chronic poisoning by aristolochia. Croat Med. J. 46 (1), 116-125. doi: 10.1503/cmaj.1040752

Hsieh, S. C., Lin, I. H., Tseng, W. L., Lee, C. H., and Wang, J. D. (2008). Prescription profile of potentially aristolochic acid containing Chinese herbal products: an analysis of National Health Insurance data in Taiwan between 1997 and 2003. Chin. Med. 3, 13. doi: 10.1186/1749-8546-3-13

Hu, S. L., Zhang, H. Q., Chan, K., and Mei, Q. X. (2004). Studies on the toxicity of Aristolochia manshuriensis (Guanmuton). Toxicology 198 (1-3), 195-201. doi: 10.1016/j.tox.2004.01.026

Huang, K., and Zhu, X. (2015). Determination of aristolochic acid I in Liujingtoutong Tablet by SPE-HPLC. Tianjin Pharmacy 27 (5), 9-11. doi: 10.3969/j.issn.1006-5687.2015.05.003

Huang, Q., Zheng, W., Chi, Z., and Lin, G. (2009). Limit detection of aristolochic acid A in Jiangusujin Tablet by HPLC. Strait Pharm. J. 21 (11), 74-75. doi: 10.3969/j.issn.1006-3765.2009.11.033

IARC (2002). Some traditional herbal medicines, some mycotoxins, naphthalene and styrene. IARC Monogr. Eval. Carcinog. Risks Hum. 82, 1-556.

IARC (2012). Pharmaceuticals. Volume 100 A. A review of human carcinogens. IARC Monogr. Eval. Carcinog. Risks Hum. 100 (Pt A), 1-401.

Ioset, J. R., Raoelison, G. E., and Hostettmann, K. (2003). Detection of aristolochic acid in Chinese phytomedicines and dietary supplements used as slimming regimens. Food Chem. Toxicol. 41 (1), 29-36. doi: 10.1016/S0278-6915(02) 00219-3

Ivic, M. (1969). Etiology of endemic nephropathy. Lijec. Vjesn. 91 (12), 1273-1281.

Jadot, I., Decleves, A. E., Nortier, J., and Caron, N. (2017). An Integrated view of aristolochic acid nephropathy: update of the literature. Int. J. Mol. Sci. 18 (2). doi: 10.3390/ijms 18020297

Jankovic-Velickovic, L., Stojnev, S., Ristic-Petrovic, A., Dolicanin, Z., Hattori, T., Mukaisho, K., et al. (2011). Pro- and antiapoptotic markers in upper tract urothelial carcinoma associated with Balkan endemic nephropathy. Sci. World J. 11, 1699-1711. doi: 10.1100/2011/752790

Jankovic-Velickovic, L., Ristic-Petrovic, A., Stojnev, S., Dolicanin, Z., Hattori, T., Sugihara, H., et al. (2012). Angiogenesis in upper tract urothelial carcinoma associated with Balkan endemic nephropathy. Int. J. Clin. Exp. Pathol. 5 (7), 674-683. doi: 10.5114/fn.2012.30530

Jelakovic, B., Castells, X., Tomic, K., Ardin, M., Karanovic, S., and Zavadil, J. (2015a). Renal cell carcinomas of chronic kidney disease patients harbor the mutational signature of carcinogenic aristolochic acid. Int. J. Cancer 136 (12), 2967-2972. doi: 10.1002/ijc.29338

Jelakovic, B., Karanovic, S., Vukovic-Lela, I., Miller, F., Edwards, K. L., Nikolic, J., et al. (2012). Aristolactam-DNA adducts in the renal cortex: biomarker of environmental exposure to aristolochic acid. Kidney Int. 81 (6), 559-567. doi: 10.1038/ki.2011.371

Jelakovic, B., Nikolic, J., Radovanovic, Z., Nortier, J., Cosyns, J. P., Grollman, A. P., et al. (2014). Consensus statement on screening, diagnosis, classification and treatment of endemic (Balkan) nephropathy. Nephrol. Dial. Transplant. 29 (11), 2020-2027. doi: 10.1093/ndt/gft384

Jelakovic, B., Vukovic Lela, I., Karanovic, S., Dika, Z., Kos, J., Dickman, K., et al. (2015b). Chronic dietary exposure to aristolochic acid and kidney function in native farmers from a Croatian endemic area and Bosnian immigrants. Clin. J. Am. Soc. Nephrol. 10 (2), 215-223. doi: 10.2215/CJN.03190314

Jia, W., Zhao, A., Gao, W., Chen, M., and Xiao, P. (2005). New perspectives on the Chinese herbal nephropathy. Phytother. Res. 19 (11), 1001-1002. doi: 10.1002/ ptr.1676

Jiang, Y., Hu, L., and Hao, F. (2007). Determination of the contents of cinnamic acid and aristolochic acid A in two Guanxinsuhe Pills by RP-HPLC. Chin. Traditional Patent Med. 29 (4), 599-601. doi: 10.3969/j.issn.1001-1528.2007.04.048

Jin, K., Su, K. K., Li, T., Zhu, X. Q., Wang, Q., Ge, R. S., et al. (2016). Hepatic premalignant alterations triggered by human nephrotoxin aristolochic acid I in canines. Cancer Prev. Res. (Phila) 9 (4), 324-334. doi: 10.1158/1940-6207. CAPR-15-0339

Jou, J. H., Li, C. Y., Schelonka, E. P., Lin, C. H., and Wu, T. S. (2004). Analysis of the analogues of aristolochic acid and aristolactam in the plant of Aristolochia genus by HPLC. J. Food Drug Anal. 12 (1), 40-45. doi: 10.1016/j.jcs.2003.11.005

Jou, J. H., Chen, S., and Wu, T. S. (2003). Facile reversed-phase HPLC resolution and quantitative determination of aristolochic acid and aristolactam analogues in traditional Chinese medicine. J. Liq. Chromatogr. Relat. Technol. 26 (18), 3057-3068. doi: 10.1081/JLC-120025422

Kabanda, A., Jadoul, M., Lauwerys, R., Bernard, A., and van Ypersele de Strihou, C. (1995). Low molecular weight proteinuria in Chinese herbs nephropathy. Kidney Int. 48 (5), 1571-1576. doi: 10.1038/ki.1995.449

Kang, D., and Li, T. (2008). Determination the content of aristolochic acid A in Hanshibi Granules by HPLC. China Med. Her. 5 (33), 17-18. doi: 10.3969/j. issn.1673-7210.2008.33.011

Kong, D., Gao, H., Li, X., Lu, J., and Dan, Y. (2015). Rapid determination of eight aristolochic acid analogues in five Aristolochiaceae plants by ultrahigh performance liquid chromatography quadrupole/time-of-flight mass spectrometry. J. Chin. Pharm. Sci. 24 (6), 364-375. doi: 10.5246/jcps.2015.06.047

Krell, D., and Stebbing, J. (2013). Aristolochia: the malignant truth. Lancet Oncol. 14 (1), 25-26. doi: 10.1016/S1470-2045(12)70596-X

Kuo, C. H., Lee, C. W., Lin, S. C., Tsai, I. L., Lee, S. S., Tseng, Y. J., et al. (2010). Rapid determination of aristolochic acids I and II in herbal products and biological samples by ultra-high-pressure liquid chromatography-tandem mass spectrometry. Talanta 80 (5), 1672-1680. doi: 10.1016/j.talanta.2009.10.003

Kuo, P. C., Li, Y. C., and Wu, T. S. (2012). Chemical constituents and pharmacology of the Aristolochia (madou ling) species. J. Tradit. Complement Med. 2 (4), 249-266. doi: 10.1016/S2225-4110(16)30111-0

Kwak, D. H., and Lee, S. (2016). Aristolochic acid I causes testis toxicity by inhibiting Akt and ERK1/2 phosphorylation. Chem. Res. Toxicol. 29 (1), 117 124. doi: $10.1021 /$ acs.chemrestox.5b00467

Kwak, D. H., Park, J. H., Lee, H. S., Moon, J. S., and Lee, S. (2014). Aristolochic acid I induces ovarian toxicity by inhibition of Akt phosphorylation. Chem. Res. Toxicol. 27 (12), 2128-2135. doi: 10.1021/tx5003854

Lemy, A., Wissing, K. M., Rorive, S., Zlotta, A., Roumeguere, T., Muniz Martinez, M. C., et al. (2008). Late onset of bladder urothelial carcinoma after kidney transplantation for end-stage aristolochic acid nephropathy: a case series with 15-year follow-up. Am. J. Kidney Dis. 51 (3), 471-477. doi: 10.1053/j.ajkd.2007. 11.015

Letouze, E., Shinde, J., Renault, V., Couchy, G., Blanc, J. F., Tubacher, E., et al. (2017). Mutational signatures reveal the dynamic interplay of risk factors and cellular processes during liver tumorigenesis. Nat. Commun. 8 (1), 1315. doi: $10.1038 / \mathrm{s} 41467-017-01358-\mathrm{x}$

Leung, E. M., and Chan, W. (2015). Comparison of DNA and RNA adduct formation: significantly higher levels of RNA than DNA modifications in the internal organs of aristolochic acid-dosed rats. Chem. Res. Toxicol. 28 (2), 248 255. doi: 10.1021/tx500423m

Li, G., Chen, S., Wu, L., Chen, J., Zhang, J., Li, X., et al. (2017). Determination of aristolochic acid I in traditional Chinese medicine by UPLC-QQQ-MS. Chin. J. Exp. Tradit. Med. Formulae 23 (13), 61-65. doi: 10.13422/j.cnki.syfjx.2017130061

Li, L., Gao, H., Wang, Z., and Wang, W. (2006). Determination of aristolochic acid A in Guanxinsuhe Preparations by RP-HPLC. China J. Chin. Mater. Med. 31 (2), 122-124. doi: 10.3321/j.issn:1001-5302.2006.02.009

Li, Q., Liu, Y., Chang, Y., Wang, L., Jia, R., and Zhao, Y. (2009). Qingnaozhitong Capsule of aristolochic acid A limited determination. Spec. Wild Econ. Anim. Plant Res. 31 (4), 61-64. doi: 10.3969/j.issn.1001-4721.2009.04.021

Li, W., Han, J., Gao, J., and Liu, C. (2007). Determination of aristolochic acid A in Rhizoma Asari and Yangxueqingnao Granules using liquid chromatography tandem mass spectrometry. Chin. J. Anal. Chem. 35 (12), 1798-1800. doi: 10.3321/j.issn:0253-3820.2007.12.025

Li, W., Hu, Q., and Chan, W. (2016). Uptake and accumulation of nephrotoxic and carcinogenic aristolochic acids in food crops grown in Aristolochia Clematitiscontaminated soil and water. J. Agric. Food Chem. 64 (1), 107-112. doi: 10.1021/ acs.jafc.5b05089

Li, Y. L., Tian, M., Yu, J., Shang, M. Y., and Cai, S. Q. (2010). Studies on morphology and aristolochic acid analogue constituents of Asarum campaniflorum and a comparison with two official species of Asari radix et rhizoma. J. Nat. Med. 64 (4), 442-451. doi: 10.1007/s11418-010-0433-6 
Li, Z., Qin, T., Wang, K., Hackenberg, M., Yan, J., Gao, Y., et al. (2015). Integrated microRNA, mRNA, and protein expression profiling reveals microRNA regulatory networks in rat kidney treated with a carcinogenic dose of aristolochic acid. BMC Genomics 16, 365. doi: 10.1186/s12864-015-1516-2

Liang, A., Gao, Y., and Zhang, B. (2017). Safety problems and measures of traditional Chinese medicine containing aristolochic acid. China Food Drug Admin. Mag. 11, 17-20.

Lin, D. C., Mayakonda, A., Dinh, H. Q., Huang, P., Lin, L., Liu, X., et al. (2017). Genomic and epigenomic heterogeneity of hepatocellular carcinoma. Cancer Res. 77 (9), 2255-2265. doi: 10.1158/0008-5472.CAN-16-2822

Lin, W., Chen, X., and Liu, K. (2014). Determination of aristolochic acid A in Tiaogu Tablets. Asia-Pac. Tradit. Mediine. 10 (10), 37-38. doi: 10.1111/ajco. 12307

Liu, C., Chen, Y., Zhao, X., Gong, L., and Wang, L. (2003). Determination of aristolochic acid A in Aristolochia mollissima Hance by RP-HPLC. Chin. Traditional Herbal Drugs 34 (12), 87-89. doi: 10.7501/j.issn.0253-2670.2003.12. 2003012619

Liu, F., Li, Z., Nie, L., Axia, A., Yuan, R., and Wang, J. (2015). Determination of aristolochic acids $\mathrm{A}$ and heavy metals in Tibetan medicine-Ershiwuweishanhu Pills. J. Tibet Univ. 30 (2), 65-70. doi: 10.16249/j.cnki.54-1034/c.2015.02.011

Liu, L., Cao, S., Ji, Y., Zhang, X., and Huang, T. (2005). Qualitative and quantitative analysis of aristolochic acids in Chinese materia medica and traditional Chinese patent medicines. Chin. Traditional Patent Med. 27 (8), 938-941. doi: 10.3969/j.issn.1001-1528.2005.08.025

Liu, Y., Han, S., Feng, Q., and Wang, J. (2011). Determination of aristolochic acids A and $\mathrm{B}$ in Chinese herbals and traditional Chinese patent medicines using ultra high performance liquid chromatography-triple quadrupole mass spectrometry. Chin. J. Chromatogr. 29 (11), 1076-1081. doi: 10.3724/SP.J.1123.2011.01076

Lord, G. M., Cook, T., Arlt, V. M., Schmeiser, H. H., Williams, G., and Pusey, C. D. (2001). Urothelial malignant disease and Chinese herbal nephropathy. Lancet 358 (9292), 1515-1516. doi: 10.1016/S0140-6736(01)06576-X

Lord, G. M., Hollstein, M., Arlt, V. M., Roufosse, C., Pusey, C. D., Cook, T., et al. (2004). DNA adducts and p53 mutations in a patient with aristolochic acidassociated nephropathy. Am. J. Kidney Dis. 43 (4), e11-17. doi: 10.1053/j.ajkd. 2003.11.024

Lord, G. M., Tagore, R., Cook, T., Gower, P., and Pusey, C. D. (1999). Nephropathy caused by Chinese herbs in the UK. Lancet 354 (9177), 481-482. doi: 10.1016/ S0140-6736(99)03380-2

Lukin, M., Zaliznyak, T., Johnson, F., and de los Santos, C. (2012). Structure and stability of DNA containing an aristolactam II-dA lesion: implications for the NER recognition of bulky adducts. Nucleic Acids Res. 40 (6), 2759-2770. doi: 10.1093/nar/gkr1094

Luo, Q. (2013). Determination of aristolochic acid A in Ershiwuweishanhu Pill by HPLC. Drug Clinic 10 (14), 37-39. doi: 10.3969/j.issn.1672-2809.2013.14.010

Lv, Q. (2015). Limit test of aristolochic acid A in Zhuifengtougu Capsules. Chin. J. Modern Drug Appl. 9 (15), 285-286. doi: 10.14164/j.cnki.cn11-5581/r.2015.15.196

Lv, Y., Que, Y., Su, Q., Li, Q., Chen, X., and Lu, H. (2016). Bioinformatics facilitating the use of microarrays to delineate potential miRNA biomarkers in aristolochic acid nephropathy. Oncotarget 7 (32), 52270-52280. doi: 10.18632/ oncotarget.10586

Mao, W. W., Gao, W., Liang, Z. T., Li, P., Zhao, Z. Z., and Li, H. J. (2017). Characterization and quantitation of aristolochic acid analogs in different parts of Aristolochiae Fructus, using UHPLCQ/TOF-MS and UHPLC-QQQ-MS. Chin. J. Nat. Med. 15 (5), 0392-0400. doi: 10.1016/S1875-5364(17)30060-2

Martinek, V., Barta, F., Hodek, P., Frei, E., Schmeiser, H. H., Arlt, V. M., et al. (2017). Comparison of the oxidation of carcinogenic aristolochic acid I and II by microsomal cytochromes $\mathrm{P} 450$ in vitro: experimental and theoretical approaches. Monatsh. Chem. 148 (11), 1971-1981. doi: 10.1007/s00706-017-2014-9

Martinek, V., Kubickova, B., Arlt, V. M., Frei, E., Schmeiser, H. H., Hudecek, J., et al. (2011). Comparison of activation of aristolochic acid I and II with NADPH:quinone oxidoreductase, sulphotransferases and N-acetyltranferases. Neuro. Endocrinol. Lett. 32 (Suppl 1), 57-70. doi: 10.3233/VES-2011-0426

Meinl, W., Pabel, U., Osterloh-Quiroz, M., Hengstler, J. G., and Glatt, H. (2006). Human sulphotransferases are involved in the activation of aristolochic acids and are expressed in renal target tissue. Int. J. Cancer 118 (5), 1090-1097. doi: $10.1002 / \mathrm{ijc} .21480$

Mengs, U. (1982). The carcinogenic action of aristolochic acid in rats. Arch. Toxicol. 51, 107-119. doi: 10.1007/BF00302751
Mengs, U. (1987). Acute toxicity of aristolochic acid in rodents. Arch. Toxicol. 59 (5), 328-331. doi: 10.1007/BF00295084

Mengs, U. (1988). Tumour induction in mice following exposure to aristolochic acid. Arch. Toxicol. 61 (6), 504-505. doi: 10.1007/BF00293699

Mengs, U., and Stotzem, C. D. (1993). Renal toxicity of aristolochic acid in rats as an example of nephrotoxicity testing in routine toxicology. Arch. Toxicol. 67 (5), 307-311. doi: 10.1007/BF01973700

Meyer, M. M., Chen, T. P., and Bennett, W. M. (2000). Chinese herb nephropathy. Proc. (Bayl Univ Med Cent). 13 (4), 334-337. doi: 10.1080/08998280.2000.11927699

Michl, J., Bello, O., Kite, G. C., Simmonds, M. S. J., and Heinrich, M. (2017). Medicinally used Asarum species: high-resolution LC-MS analysis of aristolochic acid analogs and in vitro toxicity screening in HK-2 cells. Front. Pharmacol. 8, 215. doi: 10.3389/fphar.2017.00215

Michl, J., Ingrouille, M. J., Simmonds, M. S., and Heinrich, M. (2014). Naturally occurring aristolochic acid analogues and their toxicities. Nat. Prod. Rep. 31 (5), 676-693. doi: 10.1039/c3np70114j

Michl, J., Jennings, H. M., Kite, G. C., Ingrouile, M. J., Simmonds, M. S., and Heinrich, M. (2013). Is aristolochic acid nephropathy a widespread problem in developing countries? A case study of Aristolochia indica L. in Bangladesh using an ethnobotanical-phytochemical approach. J. Ethnopharmacol. 149 (1), 235-244. doi: 10.1016/j.jep.2013.06.028

Michl, J., Kite, G. C., Wanke, S., Zierau, O., Vollmer, G., Neinhuis, C., et al. (2016). LC-MS- and $1 \mathrm{H}$ NMR-based metabolomic analysis and in vitro toxicological assessment of 43 Aristolochia species. J. Nat. Prod. 79 (1), 30-37. doi: 10.1021/ acs.jnatprod.5b00556

Milichovsky, J., Barta, F., Schmeiser, H. H., Arlt, V. M., Frei, E., Stiborova, M., et al. (2016). Active site mutations as a suitable tool contributing to explain a mechanism of aristolochic acid I nitroreduction by cytochromes P450 1A1, $1 \mathrm{~A} 2$ and 1B1. Int. J. Mol. Sci. 17 (2), 213. doi: 10.3390/ijms 17020213

Miyazaki, J., and Nishiyama, H. (2017). Epidemiology of urothelial carcinoma. Int. J. Urol. 24 (10), 730-734. doi: 10.1111/iju.13376

Mohamed, O. A., Wang, Z., Yu, G., and Khalid, H. E. (1999). Determination of aristolochic acid A in the roots and rhizomes of Aristolochia from Sudan and China by HPLC. J. China Pharm. Univ. 30 (4), 288-290. doi: 10.1016/ B978-008043005-8/50012-3

Moriya, M., Slade, N., Brdar, B., Medverec, Z., Tomic, K., Jelakovic, B., et al. (2011). TP53 mutational signature for aristolochic acid: an environmental carcinogen. Int. J. Cancer 129 (6), 1532-1536. doi: 10.1002/ijc.26077

Nault, J. C., and Letouze, E. (2019). Mutational processes in hepatocellular carcinoma: the story of aristolochic acid. Semin. Liver Dis. doi: 10.1055/ s-0039-1685516

Ng, A. W. T., Poon, S. L., Huang, M. N., Lim, J. Q., Boot, A., Yu, W., et al. (2017). Aristolochic acids and their derivatives are widely implicated in liver cancers in Taiwan and throughout Asia. Sci. Transl. Med. 9 (412). doi: 10.1126/ scitranslmed.aan6446

Ni, L., and Yang, X. (2012). Determination of hydroxysafflor yellow A, gallic acid, and aristolochic acid A in Wuweizhaxun Pill by HPLC. Chin. J. Exp. Tradit. Med. Formulae 18 (18), 109-112. doi: 10.13422/j.cnki.syfjx.2012.18.045

Nortier, J. L., Deschodt-Lanckman, M. M., Simon, S., Thielemans, N. O., de Prez, E. G., Depierreux, M. F., et al. (1997). Proximal tubular injury in Chinese herbs nephropathy: monitoring by neutral endopeptidase enzymuria. Kidney Int. 51 (1), 288-293. doi: 10.1038/ki.1997.35

Nortier, J. L., Martinez, M. C., Schmeiser, H. H., Arlt, V. M., Bieler, C. A., Petein, M., et al. (2000). Urothelial carcinoma associated with the use of a Chinese herb (Aristolochia fangchi). N. Engl. J. Med. 342 (23), 1686-1692. doi: 10.1056/ NEJM200006083422301

Nortier, J. L., and Vanherweghem, J. L. (2002). Renal interstitial fibrosis and urothelial carcinoma associated with the use of a Chinese herb (Aristolochia fangchi). Toxicology, 181-182, 577-580. doi: 10.1016/S0300-483X(02)00486-9

Pan, Y., and Gan, Q. (2009). Determination of aristolochic acid A in prepared traditional Chinese medicines by LC-MS/MS. Phys. Test. Chem. Anal. (Part B: Chemical Analysis) 45 (9), 1017-1020. doi: 10.1360/972009-470

Pang, Y., and Qu, J. (2015). Content determination of aristolochic acid A in Fufangquanshen Tablet. J. Pediatr. Pharm. 21 (11), 46-49. doi: 10.13407/j.cnki. jpp.1672-108X.2015.011.016

Patel, N., Arya, M., Muneer, A., Powles, T., Sullivan, M., Hines, J., et al. (2014). Molecular aspects of upper tract urothelial carcinoma. Urol. Oncol. 3228 (1), 28 e11-20. doi: 10.1016/j.urolonc.2012.10.002 
Pavlovic, N. M. (2013a). Balkan endemic nephropathy-current status and future perspectives. Clin. Kidney J. 6 (3), 257-265. doi: 10.1093/ckj/st049

Pavlovic, N. M., Maksimovic, V., Maksimovic, J. D., Orem, W. H., Tatu, C. A., Lerch, H. E., et al. (2013b). Possible health impacts of naturally occurring uptake of aristolochic acids by maize and cucumber roots: links to the etiology of endemic (Balkan) nephropathy. Environ. Geochem. Health 35 (2), 215-226. doi: 10.1007/s10653-012-9477-8

Poon, S. L., Huang, M. N., Choo, Y., McPherson, J. R., Yu, W., Heng, H. L., et al. (2015). Mutation signatures implicate aristolochic acid in bladder cancer development. Genome Med. 7 (1), 38. doi: 10.1186/s13073-015-0161-3

Poon, S. L., Pang, S. T., McPherson, J. R., Yu, W., Huang, K. K., Guan, P., et al. (2013). Genome-wide mutational signatures of aristolochic acid and its application as a screening tool. Sci. Transl. Med. 5 (197), 197ra101. doi: 10.1126/scitranslmed. 3006086

Popovska-Jankovic, K., Noveski, P., Jankovic-Velickovic, L., Stojnev, S., Cukuranovic, R., Stefanovic, V., et al. (2016). MicroRNA profiling in patients with upper tract urothelial carcinoma associated with Balkan endemic nephropathy. Biomed. Res. Int. 2016, 7450461. doi: 10.1155/2016/7450461

Pozdzik, A. A., Berton, A., Schmeiset, H. H., Missoum, W., Decaestecker, C., Salmon, I. J., et al. (2010). Aristolochic acid nephropathy revisited: a place for innate and adaptive immunity? Histopathology 56 (4), 449-463. doi: 10.1111/j. 1365-2559.2010.03509.x

$\mathrm{Pu}, \mathrm{X}$. Y., Shen, J. Y., Deng, Z. P., and Zhang, Z. A. (2016). Oral exposure to aristolochic acid I induces gastric histological lesions with non-specific renal injury in rat. Exp. Toxicol. Pathol. 68 (6), 315-320. doi: 10.1016/j.etp.2016.03.003

Qiu, Q., Qin, C., and Huang, Q. (2018). Determination of aristolochic acid A in Shennong snake liquor by HPLC. J. Guangxi Med. Univ. 35 (1), 116-118. doi: 10.16190/j.cnki.45-1211/r.2018.01.033

Ran, H., Tian, R., and Huang, J. (2016). Determination of aristolochic acid I, oxypaeoniflorin, alibiflorin, and paeoniflorin in Yangyinjiangya Capsules by HPLC. Drugs Clinic 31 (11), 1703-1706. doi: 10.7501/j.issn.1674-5515.2016.11.004

Reginster, F., Jadoul, M., and Van Ypersele de Strihou, C. (1997). Chinese herbs nephropathy presentation, natural history and fate after transplantation. Nephrol. Dial. Transplant. 12 (1), 81-86. doi: 10.1093/ndt/12.1.81

Ren, W., Li, S., Long, Y., Su, Z., and Zhao, X. (2010). Limit detection of aristolochic acid A in Xinsheng Granula by HPLC. Tradit. Chin. Drug Res. Clin. Pharmacol. 21 (1), 67-69. doi: 10.19378/j.issn.1003-9783.2010.01.023

Rosenquist, T. A., and Grollman, A. P. (2016). Mutational signature of aristolochic acid: clue to the recognition of a global disease. DNA Repair 44, 205-211. doi: 10.1016/j.dnarep.2016.05.027

Rosenquist, T. A., Einolf, H. J., Dickman, K. G., Wang, L., Smith, A., and Grollman, A. P. (2010). Cytochrome P450 1A2 detoxicates aristolochic acid in the mouse. Drug Metab. Dispos. 38 (5), 761-768. doi: 10.1124/dmd.110.032201

Ruan, Y., Hu, X., and Zhao, Y. (2012). Effect of Chinese herbal medicine compatibility on aristolochic acid content in Dangguisini Decoction. Chin. Arch. Tradit. Chin. Med. 30 (3), 549-551. doi: 10.13193/j.archtcm.2012.03.103. ruanyp.049

Rui, H. L., Wang, Y. Y., Cheng, H., and Chen, Y. P. (2012). JNK-dependent AP-1 activation is required for aristolochic acid-induced TGF-betal synthesis in human renal proximal epithelial cells. Am. J. Physiol. Renal Physiol. 302 (12), F1569-1575. doi: 10.1152/ajprenal.00560.2011

Sato, N., Takahashi, D., Chen, S. M., Tsuchiya, R., Mukoyama, T., Yamagata, S., et al. (2004). Acute nephrotoxicity of aristolochic acids in mice. J. Pharm. Pharmacol. 56 (2), 221-229. doi: 10.1211/0022357023051

Scelo, G., Riazalhosseini, Y., Greger, L., Letouneau, L., Gonzalea-Porta, M., Wozniak, M. B., et al. (2014). Variation in genomic landscape of clear cell renal cell carcinoma across Europe. Nat. Commun. 5, 5135. doi: 10.1038/ncomms6135

Schaneberg, B. T., and Khan, I. A. (2004). Analysis of products suspected of containing Aristolochia or Asarum species. J. Ethnopharmacol. 94 (2-3), 245249. doi: 10.1016/j.jep.2004.06.010

Schmeiser, H. H., Bieler, C. A., Wiessler, M., van Ypersele de Strihou, C., and Cosyns, J. P. (1996). Detection of DNA adducts formed by aristolochic acid in renal tissue from patients with Chinese herbs nephropathy. Cancer Res. 56 (9), 2025-2028. doi: 10.1007/s002620050279

Schmeiser, H. H., Frei, E., Wiessler, M., and Stiborova, M. (1997). Comparison of DNA adduct formation by aristolochic acids in various in vitro activation systems by 32P-post-labelling: evidence for reductive activation by peroxidases. Carcinogenesis 18 (5), 1055-1062. doi: 10.1093/carcin/18.5.1055
Schmeiser, H. H., Janssen, J. W., Lyons, J., Scherf, H. R., Pfau, W., Buchmann, A., et al. (1990). Aristolochic acid activates ras genes in rat tumors at deoxyadenosine residues. Cancer Res. 50 (17), 5464-5469. doi: 10.1016/0304-3835(90)90217-L

Schmeiser, H. H., Kucab, J. E., Arlt, V. M., Phillips, D. H., Hollstein, M., Gluhovschi, G., et al. (2012). Evidence of exposure to aristolochic acid in patients with urothelial cancer from a Balkan endemic nephropathy region of Romania. Environ. Mol. Mutagen. 53 (8), 636-641. doi: 10.1002/em.21732

Schmeiser, H. H., Nortier, J. L., Singh, R., Gamboa da Costa, G., Sennesael, J., Cassuto-Viguier, E., et al. (2014). Exceptionally long-term persistence of DNA adducts formed by carcinogenic aristolochic acid I in renal tissue from patients with aristolochic acid nephropathy. Int. J. Cancer 135 (2), 502-507. doi: $10.1002 / \mathrm{ijc} .28681$

Shaohua, Z., Ananda, S., Ruxia, Y., Liang, R., Xiaorui, C., and Liang, L. (2010). Fatal renal failure due to the Chinese herb "GuanMuTong" (Aristolochia manshuriensis): autopsy findings and review of literature. Forensic Sci. Int. 199 (1-3), e5-7. doi: 10.1016/j.forsciint.2010.02.003

Shen, M., Xu, G., and Zhang, Q. (2008). Determination of the contents of aristolochic acid A in Longdanxiegan Pills by high performance liquid chromatography. Her. Med. 27 (2), 221-222. doi: 10.3870/j.issn.1004-0781.2008.02.043

Shibutani, S., Dong, H., Suzuki, N., Ueda, S., Miller, F., and Grollman, A. P. (2007). Selective toxicity of aristolochic acids I and II. Drug Metab. Dispos. 35 (7), 1217-1222. doi: 10.1124/dmd.107.014688

Shu, X., Chen, J., Lin, S., Yu, N., Ye, X., Xie, D., et al. (2016). Determination of limit of aritolochic acid A in Dahuangqingwei Pills. Chin. J. Hosp. Pharmacy 36 (17), 1512-1515. doi: 10.13286/j.cnki.chinhosppharmacyj.2016.17.19

Sidorenko, V. S., Attaluri, S., Zaitseva, I., Iden, C. R., Dickman, K. G., Johnson, F., et al. (2014). Bioactivation of the human carcinogen aristolochic acid. Carcinogenesis 35 (8), 1814-1822. doi: 10.1093/carcin/bgu095

Sidorenko, V. S., Yeo, J. E., Bonala, R. R., Johnson, F., Scharer, O. D., and Grollman, A. P. (2012). Lack of recognition by global-genome nucleotide excision repair accounts for the high mutagenicity and persistence of aristolactam-DNA adducts. Nucleic Acids Res. 40 (6), 2494-2505. doi: 10.1093/nar/gkr1095

Slade, N., Moll, U. M., Brdar, B., Zoric, A., and Jelakovic, B. (2009). P53 mutations as fingerprints for aristolochic acid: an environmental carcinogen in endemic (Balkan) nephropathy. Mutat. Res. 663 (1-2), 1-6. doi: 10.1016/j. mrfmmm.2009.01.005

Soria, F., Shariat, S. F., Lerner, S. P., Fritsche, H. M., Rink, M., Kassouf, W., et al. (2017). Epidemiology, diagnosis, preoperative evaluation and prognostic assessment of upper-tract urothelial carcinoma (UTUC). World J. Urol. 35 (3), 379-387. doi: 10.1007/s00345-016-1928-x

Stefanovic, V., Jelakovic, B., Cukuranovic, R., Bukvic, D., Nikolic, J., Lukic, L., et al. (2007). Diagnostic criteria for Balkan endemic nephropathy: proposal by an international panel. Ren. Fail. 29 (7), 867-880. doi: 10.1080/08860220701600732

Stefanovic, V., Toncheva, D., Atanasova, S., and Polenakovic, M. (2006). Etiology of Balkan endemic nephropathy and associated urothelial cancer. Am. J. Nephrol. 26 (1), 1-11. doi: 10.1159/000090705

Stiborova, M., Arlt, V. M., and Schmeiser, H. H. (2016). Balkan endemic nephropathy: an update on its aetiology. Arch. Toxicol. 90 (11), 2595-2615. doi: 10.1007/s00204-016-1819-3

Stiborova, M., Arlt, V. M., and Schmeiser, H. H. (2017). DNA adducts formed by aristolochic acid are unique biomarkers of exposure and explain the initiation phase of upper urothelial cancer. Int. J. Mol. Sci. 18 (10). doi: 10.3390/ ijms 18102144

Stiborova, M., Barta, F., Levova, K., Hodek, P., Schmeiser, H. H., Arlt, V. M., et al. (2015). A mechanism of O-demethylation of aristolochic acid I by cytochromes P450 and their contributions to this reaction in human and rat livers: experimental and theoretical approaches. Int. J. Mol. Sci. 16 (11), 27561-27575. doi: $10.3390 /$ ijms 161126047

Stiborova, M., Frei, E., Arlt, V. M., and Schmeiser, H. H. (2008a). Metabolic activation of carcinogenic aristolochic acid, a risk factor for Balkan endemic nephropathy. Mutat. Res. 658 (1-2), 55-67. doi: 10.1016/j.mrrev.2007.07.003

Stiborova, M., Frei, E., Arlt, V. M., and Schmeiser, H. H. (2009). The role of biotransformation enzymes in the development of renal injury and urothelial cancer caused by aristolochic acid: urgent questions and difficult answers. Biomed. Pap. Med. Fac. Univ. Palacky Olomouc Czech. Repub. 153 (1), 5-11. doi: $10.5507 /$ bp.2009.001

Stiborova, M., Frei, E., Hodek, P., Wiessler, M., and Schmeiser, H. H. (2005). Human hepatic and renal microsomes, cytochromes P450 1A1/2, NADPH:cytochrome 
P450 reductase and prostaglandin $\mathrm{H}$ synthase mediate the formation of aristolochic acid-DNA adducts found in patients with urothelial cancer. Int. J. Cancer 113 (2), 189-197. doi: 10.1002/ijc.20564

Stiborova, M., Frei, E., and Schmeiser, H. H. (2008b). Biotransformation enzymes in development of renal injury and urothelial cancer caused by aristolochic acid. Kidney Int. 73 (11), 1209-1211. doi: 10.1038/ki.2008.125

Stiborova, M., Hudecek, J., Frei, E., and Schmeiser, H. H. (2008c). Contribution of biotransformation enzymes to the development of renal injury and urothelial cancer caused by aristolochic acid: urgent questions, difficult answers. Interdiscip. Toxicol. 1 (1), 8-12. doi: 10.2478/v10102-010-0023-1

Stiborova, M., Levova, K., Barta, F., Shi, Z., Frei, E., Schmeiser, H. H., et al. (2012). Bioactivation versus detoxication of the urothelial carcinogen aristolochic acid I by human cytochrome P450 1A1 and 1A2. Toxicol. Sci. 125 (2), 345-358. doi: 10.1093/toxsci/kfr306

Stiborova, M., Mares, J., Frei, E., Arlt, V. M., Martinek, V., Schmeiser, H. H., et al. (2011). The human carcinogen aristolochic acid I is activated to form DNA adducts by human $\mathrm{NAD}(\mathrm{P}) \mathrm{H}$ :quinone oxidoreductase without the contribution of acetyltransferases or sulfotransferases. Environ. Mol. Mutagen. 52 (6), 448-459. doi: 10.1002/em.20642

Sun, M., Zhang, J., Zheng, C., Liu, Y., Lin, F., Xu, F., et al. (2015). Analysis of potential risk factors for cancer incidence in patients with aristolochic acid nephropathy from Wenzhou, China. Ren. Fail. 37 (2), 209-213. doi: 10.3109/ 0886022X.2014.990347

Tan, R., Shi, X., and Yang, J. (2005). Determination of aristolochic acid in Ershiwuwei songshi Capsule by HPLC. J. Chin. Med. Mater. 28 (7), 619-620. doi: 10.13863/j.issn1001-4454.2005.07.042

Tang, X., He, S., and Xie, T. (2012). Determination of aristolochic acid A in Xiaozhongzhitong Tincture by SPE-HPLC. Chin. J. Pharm. Anal. 32 (9), 16901693. doi: $10.16155 / j .0254-1793.2012 .09 .025$

Tao, L., Zeng, Y., Wang, J., Liu, Z., Shen, B., Ge, J., et al. (2015). Differential microRNA expression in aristolochic acid-induced upper urothelial tract cancers ex vivo. Mol. Med. Rep. 12 (5), 6533-6546. doi: 10.3892/mmr.2015.4330

Tian, H., and Wang, H. (2007). Determination of aristolochic acid A in Wantongjingu Tablet by RP-HPLC. Pharm. J. Chin. People's Liberation Army 23 (6), 456-457. doi: 10.3969/j.issn.1008-9926.2007.06.021

Toncheva, D., Mihailova-Hristova, M., Vazharova, R., Staneva, R., Karachanak, S., Dimitrov, P., et al. (2014). NGS nominated CELA1, HSPG2, and KCNK5 as candidate genes for predisposition to Balkan endemic nephropathy. Biomed. Res. Int. 2014, 920723. doi: 10.1155/2014/920723

Totoki, Y., Tatsuno, K., Covington, K. R., Ueda, H., Creighton, C. J., Kato, M., et al. (2014). Transancestry mutational landscape of hepatocellular carcinoma genomes. Nat. Genet. 46 (12), 1267-1273. doi: 10.1038/ng.3126

Trnacevic, S., Nislic, E., Trnacevic, E., and Tulumovic, E. (2017). Early screening of Balkan endemic nephropathy. Mater. Sociomed. 29 (3), 207-210. doi: 10.5455/ msm.2017.29.207-210

Vaclavik, Krynitsky, A. J., and Rader, J. I. (2014). Quantification of aristolochic acids I and II in herbal dietary supplements by ultra-high-performance liquid chromatography-multistage fragmentation mass spectrometry. Food Addit. Contam. Part A Chem. Anal. Control Expo. Risk Assess. 31 (5), 784-791. doi: 10.1080/19440049.2014.892215

Vanhaelen, M., Vanhaelen-Fastre, R., But, P., and Vanherveghem, J. L. (1994). Identification of aristolochic acid in Chinese herbs. Lancet 343 (8890), 174.

Vanherweghem, J., Depierreux, M., Tielemans, C., Abramowicz, D., Dratwa, M., Jadoul, M., et al. (1993). Rapidly progressive interstitial renal fibrosis in young women: association with slimming regimen including Chinese herbs. Lancet 341 (8842), 387-391. doi: 10.1016/0140-6736(93)92984-2

Veale, E. L., and Mathie, A. (2016). Aristolochic acid, a plant extract used in the treatment of pain and linked to Balkan endemic nephropathy, is a regulator of K2P channels. Br. J. Pharmacol. 173 (10), 1639-1652. doi: 10.1111/bph.13465

Vervaet, B. A., D'Haese, P. C., and Verhulst, A. (2017). Environmental toxininduced acute kidney injury. Clin. Kidney J. 10 (6), 747-758. doi: 10.1093/ckj/ sfx062

Wang, Y., and Chan, W. (2014). Determination of aristolochic acids by highperformance liquid chromatography with fluorescence detection. J. Agric. Food Chem. 62 (25), 5859-5864. doi: 10.1021/jf501609j

Wang, C., Juan, H., and Li, H. (2017). HPLC determination of aristolochic acid in Yishenjuanbi Pill. Journal of Harbin University of Commerce (Natural Sciences Edition). 33 (4), 406-410. doi: 10.19492/j.cnki.1672-0946.2017.04.006
Wang, H., Yang, S., and Bai, S. (2018a). Progress on chemical constituents and bioactivities of Saruma Henryi Oliv. Food Drug 20 (2), 157-160. doi: 10.3969/j. issn.1672-979X.2018.02.020

Wang, L., Ding, X., Li, C., Zhao, Y., Yu, C., Yi, Y., et al. (2018b). Oral administration of Aristolochia manshuriensis Kom in rats induces tumors in multiple organs. J. Ethnopharmacol. 225, 81-89. doi: 10.1016/j.jep.2018.07.001

Wang, S. M., Lai, M. N., Chen, P. C., Pu, Y. S., Lai, M. K., Hwang, J. S., et al. (2014a). Increased upper and lower tract urothelial carcinoma in patients with endstage renal disease: a nationwide cohort study in Taiwan during 1997-2008. Biomed. Res. Int. 2014, 149750. doi: 10.1155/2014/149750

Wang, S. M., Lai, M. N., Wei, A., Chen, Y. Y., Pu, Y. S., Chen, P. C., et al. (2014b). Increased risk of urinary tract cancer in ESRD patients associated with usage of Chinese herbal products suspected of containing aristolochic acid. PLoS One 9 (8), e105218. doi: 10.1371/journal.pone.0105218

Wang, Y., Meng, F., Arlt, V. M., Mei, N., Chen, T., and Parsons, B. L. (2011). Aristolochic acid-induced carcinogenesis examined by ACB-PCR quantification of H-Ras and K-Ras mutant fraction. Mutagenesis 26 (5), 619-628. doi: 10.1093/ mutage/ger023

Wei, F., Cheng, X. L., Ma, L. Y., Jin, W. T., Schaneberg, B. T., Khan, I. A., et al. (2005). Analysis of aristolochic acids and analogues in medicinal plants and their commercial products by HPLC-PAD-ESI/MS. Phytochem. Anal. 16 (3), 222-230. doi: 10.1002/pca.849

Wei, J., Mo, Y., and Liang, S. (2007). Limit detection of aristolochic acid in Ganteling Capsules. Chin. Traditional Patent Med. 29 (8), 1266-1267. doi: 10.3969/j.issn.1001-1528.2007.08.061

Wei, Y., Wang, H., Liu, Y., Liu, H., Han, X., and Song, X. (2011). Determination of the contents of aristolochic acid A in Aristolochia moupinensis and Qiweihonghuashusheng Pills. Chin. Traditional Patent Med. 33 (12), 21862188. doi: $10.1038 /$ cdd. 2010.68

Wen, H., Gao, H. Y., Qi, W., Xiao, F., Wang, L. L., Wang, D., et al. (2014). Simultaneous determination of twenty-two components in Asari Radix et Rhizoma by ultra performance liquid chromatography coupled with quadrupole time-of-flight mass spectrometry. Planta Med. 80 (18), 1753-1762. doi: 10.1055/s-00341383296

Wooltorton, E. (2004). Several Chinese herbal products may contain toxic aristolochic acid. CMAJ 171 (5), 449. doi: 10.1503/cmaj.1041266

Wu, F. L., Chen, Y. M., Lai, T. S., Shen, L. J., Ho, Y. F., Lee, Y. T., et al. (2012). Does Chinese herb nephropathy account for the high incidence of endstage renal disease in Taiwan? Nephron. Clin. Pract. 120 (4), c215-222. doi: $10.1159 / 000341120$

Wu, J., Wu, C., and Qiao, M. (2009). Detection on contents of aristolochic acid A in Daochi Powder and its combination group with high performance liquid chromatography. J. Hubei Univ. Chin. Med. 11 (3), 30-31. doi: 10.3969/j.issn. 1008-987X.2009.03.012

Wu, X. (2006). Determination of aristolochine A in Guanxinsuhe Pills by RP-HPLC. J. Zhejiang Chin. Med. Univ. 30 (5), 535-536. doi: 10.3969/j.issn. 1005-5509.2006.05.048

Xiao, Y., Ge, M., Xue, X., Wang, C., Wang, H., Wu, X., et al. (2008). Hepatic cytochrome P450s metabolize aristolochic acid and reduce its kidney toxicity. Kidney Int. 73 (11), 1231-1239. doi: 10.1038/ki.2008.103

Xing, G., Qi, X., Chen, M., Wu, Y., Yao, J., Gong, L., et al. (2012). Comparison of the mutagenicity of aristolochic acid I and aristolochic acid II in the gpt delta transgenic mouse kidney. Mutat. Res. 743 (1-2), 52-58. doi: 10.1016/j. mrgentox.2011.12.021

Xu, Y., Shang, M., Ge, Y., Wang, X., and Cai, S. (2010). Chemical constituent from fruit of Aristolochia contorta.. China J. Chin. Mater. Med. 35 (21), 2862-2865. doi: $10.4268 / \mathrm{cjcmm} 20102115$

Xu, Y. Q., Li, X. W., Liu, G. X., Wang, X., Shang, M. Y., Li, X. M., et al. (2013). Comparative study of the contents of analogues of aristolochic acid in two kinds of Aristolochiae Fructus by high-performance liquid chromatography. J. Nat. Med. 67 (1), 113-122. doi: 10.1007/s11418-012-0664-9

Xue, L. (2015). Determination of the content of aristolochic acid in Rumozhentong Capsule. Shanxi J. Traditional Chin. Med. 36 (4), 492-493. doi: 10.3969/j.issn. 1000-7369.2015.04.049

Xue, X., Gong, L. K., Maeda, K., Luan, Y., Qi, X. M., Sugiyama, Y., et al. (2011). Critical role of organic anion transporters 1 and 3 in kidney accumulation and toxicity of aristolochic acid I. Mol. Pharm. 8 (6), 2183-2192. doi: 10.1021/ mp100418u 
Yang, H. Y., Chen, P. C., and Wang, J. D. (2014). Chinese herbs containing aristolochic acid associated with renal failure and urothelial carcinoma: a review from epidemiologic observations to causal inference. Biomed. Res. Int. 2014, 569325. doi: 10.1155/2014/569325

Yang, H. Y., Lin, J. L., Chen, K. H., Yu, C. C., Hsu, P. Y., and Lin, C. L. (2006). Aristolochic acid-related nephropathy associated with the popular Chinese herb Xixin. J. Nephrol. 19 (1), 111-114. doi: 10.1016/S0269-7491(99)00120-7

Yang, L., Su, T., Li, X. M., Wang, X., Cai, S. Q., Meng, L. Q., et al. (2012). Aristolochic acid nephropathy: variation in presentation and prognosis. Nephrol. Dial. Transplant. 27 (1), 292-298. doi: 10.1093/ndt/gfr291

Ye, Z., Zhang, Y., and Wang, Y. (2003). Determination of aristolonchic acid A content in Caulis Aristolochiae Manshuriensis and other four aristolonchic Chinese herb drugs by HPLC. Fudan Univ. J. Med. Sci. 30 (5), 491-493. doi: 10.3969/j.issn.1672-8467.2003.05.022

Yi, J. H., Han, S. W., Kim, W. Y., Kim, J., and Park, M. H. (2018). Effects of aristolochic acid I and/or hypokalemia on tubular damage in C57BL/6 rat with aristolochic acid nephropathy. Korean J. Intern. Med. 33 (4), 763-773. doi: 10.3904/kjim.2016.097

Yin, S., Wang, M., Lin, X., Li, J., and Xie, H. (2009). Determination of aristolochic acid A in Fufangnanxingzhitong Ointment by UPLC. J. Nanjing Univ. Tradit. Chinese Med. 25 (5), 396-397. doi: 10.3969/j.issn.1000-5005.2009.05.025

Yu, B., Liu, Z., and Li, S. (2011a). Limit detection of aristolochic acid I in Gubenqufeng Granules. China Pharmacy 22 (47), 4485-4486.

Yu, F., Wu, T. S., Chen, T. W., and Liu, B. H. (2011b). Aristolochic acid I induced oxidative DNA damage associated with glutathione depletion and ERK1/2 activation in human cells. Toxicol. Vitro 25 (4), 810-816. doi: 10.1016/j.tiv.2011. 01.016

Yu, J., Ma, C. M., Wang, X., Shang, M. Y., Hattori, M., Xu, F., et al. (2016). Analysis of aristolochic acids, aristololactams and their analogues using liquid chromatography tandem mass spectrometry. Chin. J. Nat. Med. 14 (8), 06260640. doi: 10.1016/S1875-5364(16)30074-7

Yuan, J., Liu, Q., Wei, G., Tang, F., Ding, L., and Yao, S. (2007a). Characterization and determination of six aristolochic acids and three aristololactams in medicinal plants and their preparations by high-performance liquid chromatographyphotodiode array detection/electrospray ionization mass spectrometry. Rapid Commun. Mass Spectrom. 21 (14), 2332-2342. doi: 10.1002/rcm.3097

Yuan, J., Liu, Q., Zhu, W., Ding, L., Tang, F., and Yao, S. (2008). Simultaneous analysis of six aristolochic acids and five aristolactams in herbal plants and their preparations by high-performance liquid chromatography-diode array detection-fluorescence detection. J. Chromatogr. A 1182 (1), 85-92. doi: 10. 1016/j.chroma.2007.12.076

Yuan, J., Nie, L., Zeng, D., Luo, X., Tang, F., and Ding, L. (2007b). Simultaneous determination of nine aristolochic acid analogues in medicinal plants and preparations by high-performance liquid chromatography. Talanta 73 (4), 644650. doi: 10.1016/j.talanta.2007.04.042

Yuan, J., and Zhang, X. (2016). Simultaneous determination of contents of five components in Guanxinsuhe dripping Pills by HPLC with gradient elution method. Anhui Med. Pharm. J. 20 (9), 1651-1654. doi: 10.3969/j.issn.10096469.2016.09.010

Zhai, Z., Luo, X., and Shi, Y. (2006). Separation and determination of aristolochic acids in herbal medicines by microemulsion electrokinetic chromatography. Anal. Chim. Acta 561 (1-2), 119-125. doi: 10.1016/j.aca.2006.01.025

Zhang, C., Wang, X., Shang, M., Yu, J., Xu, Y., Li, Z., et al. (2006). Simultaneous determination of five aristolochic acids and two aristololactams in Aristolochia plants by high-performance liquid chromatography. Biomed. Chromatogr. 20 (4), 309-318. doi: 10.1002/bmc.565

Zhang, H., Li, J., and Sun, X. (2013a). Determination of aristolochic acid I in Ershijiuweinengxiao Powder by HPLC. Chin. Pharm. Affairs 27 (12), 1269-1271.

Zhang, H. M., Zhao, X. H., Sun, Z. H., Li, G. C., Liu, G. C., Sun, L. R., et al. (2019). Recognition of the toxicity of aristolochic acid. J. Clin. Pharm. Ther. 44 (2), 157-162. doi: 10.1111/jcpt.12789

Zhang, H. (2017). Limited determination of aristolochic acid I in Biyanling Tablet. Chin. J. Ration. Drug Use 14 (7), 67-69. doi: 10.3969/j.issn.2096-3327.2017.07.020

Zhang, J., Wei, Z., Zhang, A., Zhao, Y., Zhao, G., Cai, X., et al. (2016). Detection aristolochic acids 1 and 2 in Costustoot via electrochemical method and liquid chromatography. Int. J. Electrochem. Sci. 11 (8), 6830-6837. doi: 10.20964/2016. 08.11

Zhang, L., and Wang, Y. (2012). LC-MS detection of aristolochic acid A in Xiaofengzhiyang Granula. Chin. J. Pharm. Anal. 32 (1), 78-81. doi: 10.16155/j. 0254-1793.2012.01.006

Zhang, P. (2011). The assay of aristolochic acid A in different organs of Saruma. North. Hortic. (20), 177-178.

Zhang, P., Wei, J., Zhang, F., and Gu, J. (2013b). Extraction and determination of four different aristolochic acids in aristolochic herbs and Chinese patent drug. Mod. Tradit. Chin. Med. Mater. Med. World Sci. Technol. 15 (1), 6. doi: 10.3969/j.issn.1674-3849.2013.01.025

Zhao, H., and Jiang, H. (2009). Determination of aristolochic acid A in Saruma henryi by HPLC. Guihaia 29 (4), 548-551. doi: 10.3969/j.issn.1000-3142.2009. 04.027

Zhao, Y. Y., Wang, H. L., Cheng, X. L., Wei, F., Bai, X., Lin, R. C., et al. (2015). Metabolomics analysis reveals the association between lipid abnormalities and oxidative stress, inflammation, fibrosis, and Nrf2 dysfunction in aristolochic acid-induced nephropathy. Sci. Rep. 5, 12936. doi: 10.1038/srep12936

Zhou, Q., Pei, J., Poon, J., Lau, A. Y., Zhang, L., Wang, Y., et al. (2019). Worldwide research trends on aristolochic acids (1957-2017): suggestions for researchers. PLoS One 14 (5), e0216135. doi: 10.1371/journal.pone.0216135

Zhou, X., Li, Z., Chen, Y., and Li, P. (2015). Determination the limitation of aristolochic acid A in Mahuangzhisou Pill by SPE-HPLC. Guiding J. Tradit. Chin. Med. Pharmacy 21 (14), 44-46. doi: 10.13862/j.cnki.cn43-1446/r.2015. 14.014

Zhou, Y., Zhou, J., Huang, S., Wu, P., Wang, Y., Du, X., et al. (2008). RP-HPLC determination of aristolochic acid A in some Aristolochiaceae Chinese herbal medicine. Chin. J. Pharm. Anal. 28 (7), 1075-1080. doi: 10.1016/S1872-2040 (08)60074-2

Zhu, G., Wang, Q., Wang, Z., and Su, X. (2006). Determination of the content of aristolochic acid I and II in Ganluxiaodu Pills with RP-HPLC. Her. Med. 25 (6), 568-570. doi: 10.3870/j.issn.1004-0781.2006.06.035

Conflict of Interest Statement: The authors declare that the research was conducted in the absence of any commercial or financial relationships that could be construed as a potential conflict of interest.

Copyright (c) 2019 Han, Xian, Zhang, Liu and Liang. This is an open-access article distributed under the terms of the Creative Commons Attribution License (CC BY). The use, distribution or reproduction in other forums is permitted, provided the original author(s) and the copyright owner(s) are credited and that the original publication in this journal is cited, in accordance with accepted academic practice. No use, distribution or reproduction is permitted which does not comply with these terms. 